\title{
Article \\ Grid Operation Assessment under a Specific EV Chargers Deployment Plan in the City of Heraklion
}

\author{
Emmanuel Karapidakis ${ }^{1, *(D)}$, Antonis Tsikalakis ${ }^{1}$, Alexandros Paspatis ${ }^{1}$ D, Emmanuel Fotakis ${ }^{2}$, \\ George Stavrakakis ${ }^{3}$, Christina Chatzipoulka ${ }^{3}$ iD and Panagiotis Zervas $^{3}$ \\ 1 Department of Electrical and Computer Engineering, Hellenic Mediterranean University, \\ GR-71410 Heraklion, Greece; tsikalant@hmu.gr (A.T.); agpaspatis@hmu.gr (A.P.) \\ 2 Department of Environment, Division of Agricultural Development, Environment and Trade, \\ Municipality of Heraklion, GR-71601 Heraklion, Greece; fotakis-m@heraklion.gr \\ 3 MES Energy SA, 67 Aeolou Str., GR-10559 Athens, Greece; gstavrakakis@mese.gr (G.S.); \\ cchatzipoulka@mese.gr (C.C.); pzervas@mese.gr (P.Z.) \\ * Correspondence: karapidakis@hmu.gr; Tel.: +30-2810-379-889
}

check for updates

Citation: Karapidakis, E.; Tsikalakis, A.; Paspatis, A.; Fotakis, E.; Stavrakakis, G.; Chatzipoulka, C.;

Zervas, P. Grid Operation Assessment under a Specific EV Chargers Deployment Plan in the City of Heraklion. Electronics 2021, 10, 2831. https://doi.org/10.3390/electronics 10222831

Academic Editor: Jahangir Hossain

Received: 13 October 2021

Accepted: 16 November 2021

Published: 18 November 2021

Publisher's Note: MDPI stays neutral with regard to jurisdictional claims in published maps and institutional affiliations.

Copyright: (c) 2021 by the authors. Licensee MDPI, Basel, Switzerland. This article is an open access article distributed under the terms and conditions of the Creative Commons Attribution (CC BY) license (https:// creativecommons.org/licenses/by/ $4.0 /)$.

\begin{abstract}
The development of electric vehicles (EVs) as part of the electrification of the transportation sector plays a significant role in energy transition to a low-carbon and highly renewable society. The use of EVs has been promoted through the development of inclusive strategies for electromobility in the recent years. Apart from actions directed and funded by the European Union, national strategies have also been employed to support electromobility. Such a strategic plan has already been enacted by the Hellenic Ministry of Environment and Energy, funding municipalities to prepare siting and sizing plans for electric vehicle chargers. In this paper, the final study of this strategic plan for the municipality of Heraklion in Crete is used as a case study to investigate the effect of EV chargers on the operation of the Cretan power system. Their selected siting points are evaluated by performing a power flow analysis at the level of $150 \mathrm{kV}$. Thus, they are aggregated in each $20 \mathrm{kV} / 150 \mathrm{kV}$ distribution substation of the electrical grid with the aim of investigating their effect on substation loading and transmission line losses. Generally, extensive fast charging should be avoided to minimize the risk of sudden stress of the existing cities' grids and control strategies should be implemented to mitigate the need for upscale substation equipment or even postpone reinforcements.
\end{abstract}

Keywords: electric vehicles; chargers; electrical grids

\section{Introduction}

Electric vehicles (EVs) penetration is becoming higher and higher as the battery technology advances and more sophisticated market schemes are proposed. Greece is in an early stage of EV adoption, but there already are significant incentives, which aim to subsidize the purchase of EVs and chargers with the goal of installing 1000 new charging stations in the next few years and 10,000 charging points in the medium term.

We are focusing on the cities, which are coping with unprecedented changes $[1,2]$ that will be founded on smart interventions [3] underpinned by resilience and sustainability goals [4]. The transport sector plays an important role, particularly with relation to the environment, as it is responsible for almost one-quarter of energy-related emissions [5]. Conventional transport systems dominated by private cars, which are typically vehicles with internal combustion engines, have generated severe environmental consequences [6], deterioration of air quality, and greenhouse gas (GHG) emissions [7]. Therefore, the adoption of strategies and policies that might strengthen cities' efficiency and sustainability is necessary. Due to the technological advances, new ways and opportunities are emerging [8]. Now, a shift from the conventional to a more environmentally friendly vehicle fleet in urban environments could be an adequate driver for a more viable future [9]. Clean energy 
and decarbonization should be fundamental pillars in this direction, and key to this shift is electric mobility [10], and specifically the adoption of EVs [11].

However, the adoption of EVs on a large scale is expected to give rise to both challenges and opportunities from the technical and economic perspectives [12]. Among these, an increased number of EVs simultaneously charging using an electrical grid also poses a challenge for the power system operation $[13,14]$.

It is reasonable to assume that in case of an extensive number of EVs, the electrical grid will possibly be burdened. The problem might be even more intensive in a particular case where owners of EVs would charge faster with higher currents [15]. However, EVs could provide ancillary power system services, alleviating constraints [16] and congestion [17].

The assessment of the additional demand caused by the charging of EVs on the island of Crete is presented in this paper. Thus, any necessary investments in equipment or more sophisticated control strategies based on the number of customers served can be timely scheduled so that the power system of Crete can effectively adapt to the upcoming electric mobility changes.

More precisely, in this paper, the EV hosting capacity of the power network of the metropolitan area of the City of Heraklion on the island of Crete is analyzed. Section 2 makes a short introduction into the main points of the electric vehicles' technology and their characteristics, describes the examined transmission and distribution network, and the deployment plan of EV chargers in the metropolitan area of the City of Heraklion. The next Section 3 describes the methods to estimate the future energy needs of electric vehicles, whereas Sections 4 and 5 present the results and the overall conclusions.

\section{Case Study Description}

All electric vehicles are powered through an external charging system, which is mainly part of a distribution grid. Standalone systems with RES as the primary source, supported by BESS, can be considered an exception.

\subsection{Electric Vehicle Charger Types}

Electric vehicles can be categorized as hybrid electric vehicles, all-electric or batteryelectric vehicles (BEVs), and plug-in hybrid vehicles (PHEVs). The latter two categories can be recharged from an external source of electricity using either wall sockets or specific charger circuits. EVs charge from conventional power outlets or dedicated charging stations, a process that typically takes hours but can be done overnight and often provides a charge that is sufficient for normal everyday use. There are four main charging methods:

- Mode 1 (AC charging) in which the vehicle is connected to the power grid through standard socket outlets present in residences.

- Mode 2 (AC charging via a single-phase or three-phase network) in which the vehicle is connected to the main power grid via household socket outlets with a cableincorporated protection device.

- Mode 3 (AC charging) in which the vehicle connects directly to the electrical network via specific socket and a dedicated circuit

- Mode 4 (DC charging) in which the electric vehicle is connected to the main power grid through an external charger.

For a slow charge, usually, $3.7 \mathrm{~kW}$ maximum at $230 \mathrm{~V}$ single-phase $\mathrm{AC}$ and the maximum current of $16 \mathrm{~A}$, the charging time takes 6- $8 \mathrm{~h}$. For normal charging, up to $7.4 \mathrm{~kW}$ and the maximum current of $32 \mathrm{~A}$, the charging time lasts 3-4 h. On the other hand, a quicker charge at $22 \mathrm{~kW}$ and $400 \mathrm{~V}$ three-phase AC lasts 1-2 h, while at $43 \mathrm{~kW}$ and $400 \mathrm{~V}$ three-phase AC-only 20-30 min. Finally, fast charging at 50-135 kW and 400-500 V DC may take only $10 \mathrm{~min}$. 


\subsection{Power System of the Island of Crete and Distribution Grid of the City of Heraklion}

In Crete, there are currently three (3) thermal power plants in operation. The first power plant is located in the western part of the island, the second-in the center, in close vicinity to Heraklion, the biggest city on the island, and the third-in the eastern part. Their total capacity is approximately $800 \mathrm{MW}$. In particular, the local conventional production system consists of eight steam generators (200 MW), six diesel generators (170 MW), one combined cycle unit (130 MW), and five gas generators (300 MW). In parallel, since July of 2021, the power system of Crete has been interconnected with the mainland of Greece though a submarine AC cable of 200 MVA capacity. Furthermore, the second interconnection with the mainland of Greece is planned to be in operation in 2023. The current power system of the island of Crete with the planned expansions is depicted in Figure 1.

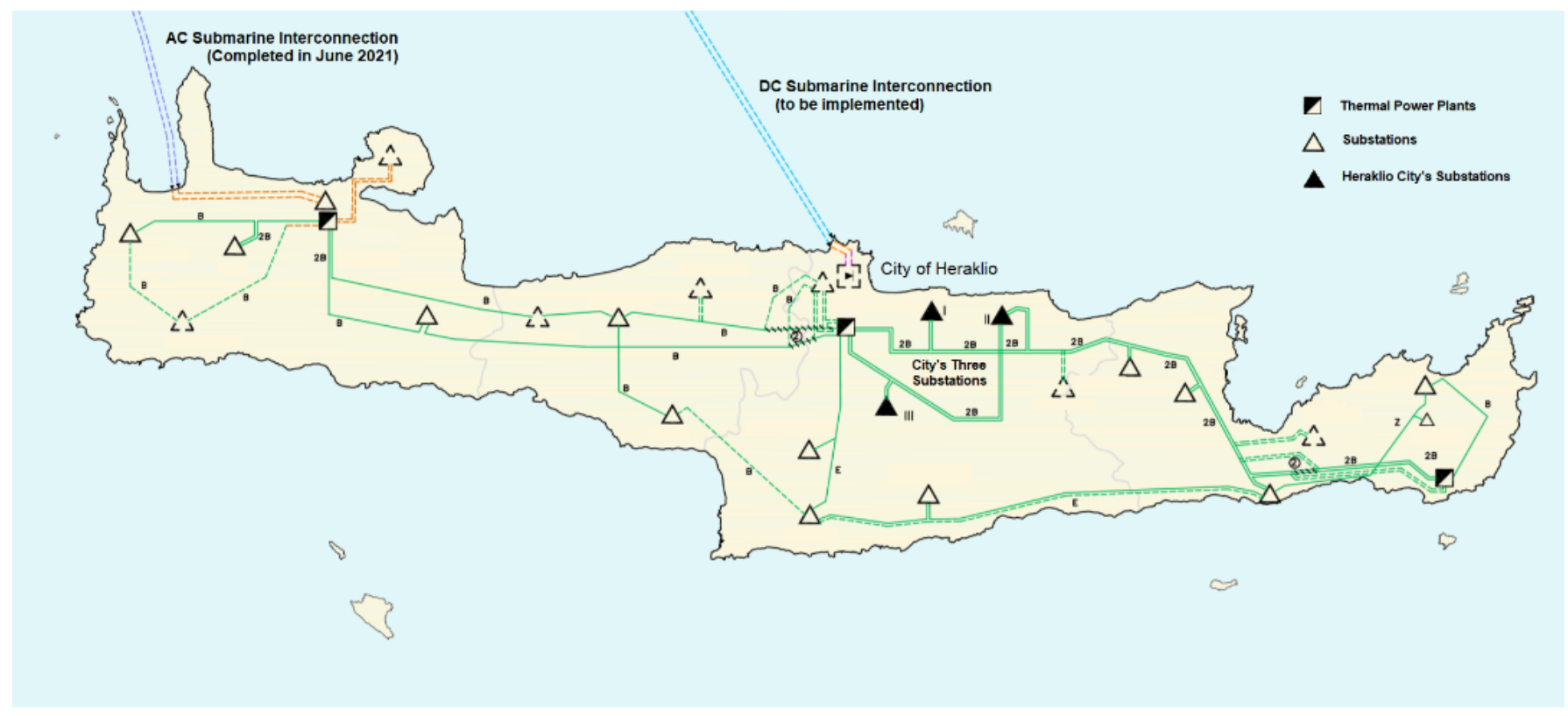

Figure 1. Single-line diagram of the $150 \mathrm{kV}$ transmission system of the island of Crete.

Additionally, the power system of Crete has a total capacity of RES of 320 MW. Among them, $210 \mathrm{MW}$ correspond to wind parks and $110 \mathrm{MW}$ correspond to photovoltaic parks and rooftop PV panels. As one can easily understand, the installed RES capacity is high, providing above $25 \%$ of the demand of the island; however, it causes various issues due to its intermittent nature. High RES penetration in combination with the semiautonomous character of the island and the need for significant local production are the main factors that led to the need for investigation of the grid operation with a significant EV fleet.

The distribution grid of the City of Heraklion, the subject of the case study of this research, is at the level of $20 \mathrm{kV}$, and its feeders start from three high-to-medium voltage (HV/MV) substations. The single-line diagram of the medium voltage $(20 \mathrm{kV})$ distribution network of the city is presented in Figure 2. 


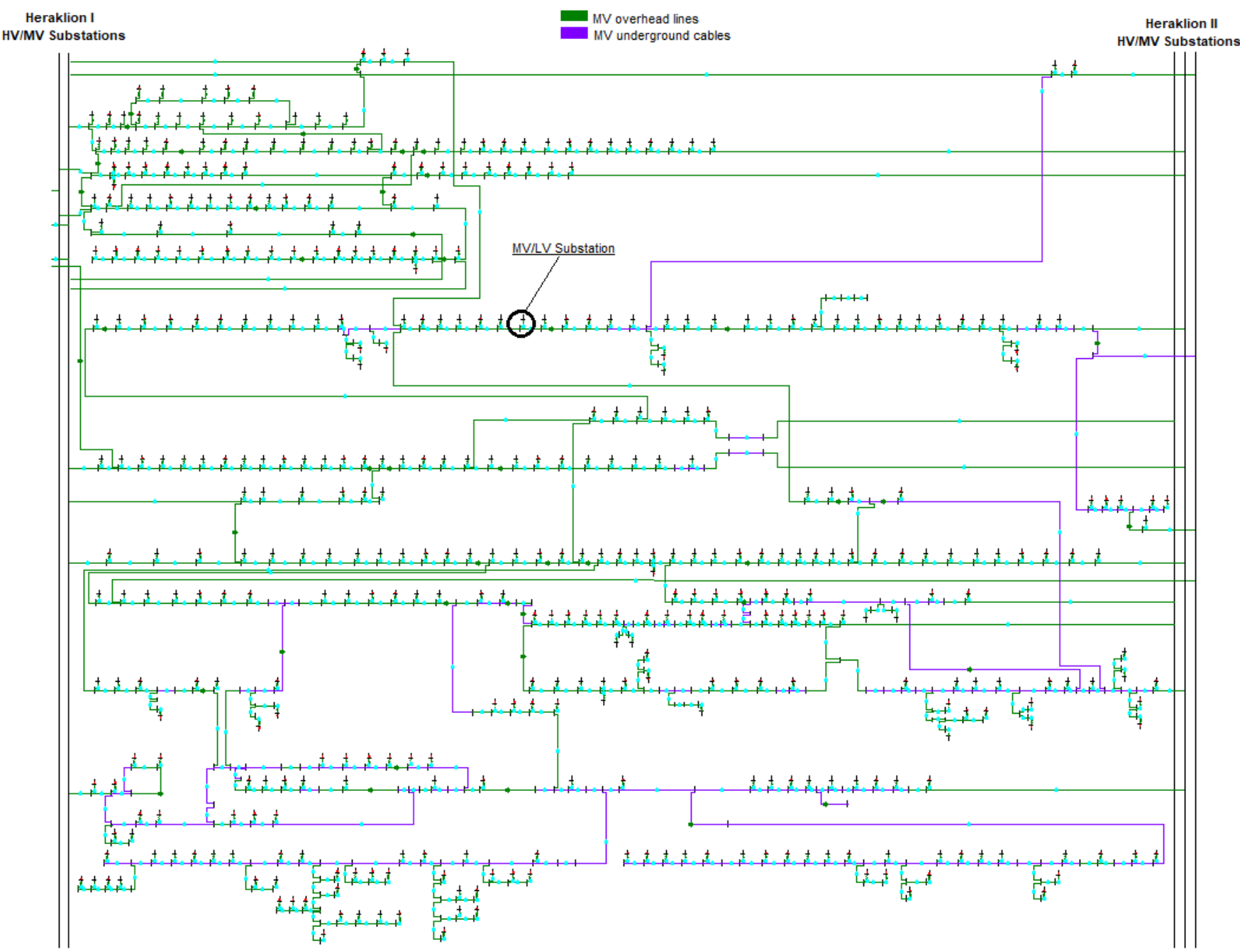

Figure 2. Single-line diagram of the distribution grid of the Heraklion metropolitan area.

\subsection{EV Charger Deployment Plan in the City of Heraklion}

According to the Greek legislation (article 17, L. 4710/2020), Greek municipalities are obliged to develop EV charging plans within their administrative boundaries, envisaging reliable locations of an adequate number of publicly accessible normal- and high-power EV chargers as well as of the associated parking spots. An EV charging plan takes into account the special characteristics regarding urban planning and land use, as well as the transportation parameters, towards the recognition of the most suitable areas to install EV chargers. To facilitate the local authorities' processes in preparing EV charging plans, the Hellenic Ministry of Environment and Energy issued a complementary decision entitled “Technical Directions for EV Charging Plans" (decision 4380 B/5.10.2020 as published in the national governmental gazette) providing the specific guidelines and methodological steps for the assessment of the current situation of the area of intervention and for identifying and prescribing the most suitable EV station and parking spaces.

Triggered by the aforementioned regulation, the municipality of Heraklion in Crete is perhaps the first Greek local authority which initiated the appropriate administrative and technical processes for the conduct of its EV charging plan. The municipality of Heraklion is the largest municipality in Crete in terms of population: 173,993 inhabitants (based on the last official census conducted in 2011) (according to Eurostat's forecasts (https: / / ec.europa.eu/eurostat/statistical-atlas/gis/viewer (accessed on 27 September 2021), also published in Heraklion's Sustainable Energy and Climate Action Plan (SECAP) in 2020 in the framework of the covenant of Mayors, in 2019, the population was estimated to 
be at least 175,443 inhabitants). The municipality extends to around $245 \mathrm{~km}^{2}$, including the largest city in Crete, Heraklion, and more than 30 settlements and villages, presenting a variety in socioeconomic conditions, especially in terms of business and activities. The main urban complex of the City of Heraklion hosts retail, technical, and engineering activities, medical services, etc., while the suburban areas host mainly touristic services and primary production services. According to the municipality's sustainable mobility plan (SUMP) (https://svakheraklion.com/ (accessed on 27 September 2021)), the following mix of vehicles' types is recorded:

- Passenger (single-family) cars/taxis/semi-vans: $75.9 \%$

- Two-wheelers: $21.5 \%$

- Heavy-duty vehicles: $1.1 \%$

- Buses: $0.9 \%$

- Bicycles: $0.6 \%$

The aforementioned distribution advocates that the expected near-future charging needs will most probably refer to passenger single-family cars and two-wheelers.

Based on the technical guidelines indicated by the regulatory framework mentioned above, the following methodological steps were implemented for the development of the EV charging plan for the municipality of Heraklion:

\subsubsection{Step 1: Analysis of the Existing Situation in the Area of Intervention}

In the first step, all the necessary information regarding the indicators which define the spatial distribution of the expected needs for EV charging stations was collected and analyzed, namely:

- Existing parking spaces of all kinds, e.g., municipal open and closed parking spaces, fee-based parking spaces, free-of-charge parking spaces (mainly on-street ones), publicly available private parking areas, etc.

- Exploitation of the official urban plan and land use characteristics

- Transport conditions in terms of hierarchy of the road network, transport flows including public transportation vehicles (e.g., taxis, buses, tourist buses, etc.);

- Special mobility networks mainly connecting the hubs, i.e., the port, the airport, and stations of intercity buses

- Information regarding the distribution of environmental stresses found in previous studies

- $\quad$ Existing parking spaces for people with disabilities (PWD)

- Taxi stations

- Attraction poles such as cultural buildings, tertiary buildings, public and medical service buildings, gymnasiums, banks, hospitals, etc.

All the above data were digitally depicted in the intervention area's map facilitating the prioritization of the subregions by means of the expected needs for EV charging stations.

\subsubsection{Step 2: Locating the EV Stations}

Based on the above analysis and identification of the "hottest" subregions, the next step was focused on digitally placing the most appropriate locations for EV chargers. The following process was conducted:

- The highest number of chargers was placed in the subregions considered the hottest by the process in step 1 .

- The network of charging stations propagates to a coarser assembly as moving far from the "hottest" subregions; nonetheless, stations are also envisaged to cover well suburban areas and villages.

- Charging spots for heavy-duty vehicles are envisaged at intermediate terminal bus stations, apart from the central terminals, to serve bus routes which never visit the central terminals during the day. 
- $\quad$ According to the regulations, charging spots are also foreseen at representative taxi stations and in the end of the waiting "tail" of each station presuming the necessary parking space for up to two electric taxis depending on space availability.

- Charging stations are also proposed in selected parking spaces for vehicles of people with disabilities (PWD) for at least $2 \%$ of the existing parking spaces of this kind.

\subsubsection{Step 3: Development of the EV Charging Plan}

In the final step, the parking spaces as well as the thematic properties (nominal power, charging slots, etc.) are determined for each station depending on the primary vehicle expected to be charged and the acceptable charging time in relation to the vehicle type. The stations are now designed at the level of street acne demonstrating the location of the station and the associated parking spaces. Additional spatial planning parameters are considered to comply with regulations related to restrictions to the pedestrians' free passage, restrictions regarding distances between the station and the parking spaces, the minimum allowed distances between parking spaces, etc. (Greek decision 2040 B/4.6.2019 published in the national governmental gazette). During this final design process, internal consultation procedures took place mainly with the key municipality services and decisionmakers.

Throughout the planning process, stakeholders' consultations were organized to obtain feedback regarding the suggested locations of EV chargers and the associated parking spaces. Special focus was concentrated on the bodies which are responsible for very interesting parking areas, within which EV charging stations are suggested; for instance, gymnasiums, public transport central terminals, universities (the Hellenic Mediterranean University and the University of Crete), research centers (Foundation for Research and Technology-Hellas), other private closed and open parking areas. In this framework, targeted informative sheets were developed including data that refer to the suggested charging equipment, i.e., technical properties, investment costs, but also important financial indicators such as estimated NPV and payback periods for the suggested investments, and provided to the interested bodies. At this stage, the municipality continues discussions with the key stakeholders and at least an initial agreement has been signed with most interested bodies; however, the final spatial planning in the areas of these bodies is still pending. Hence, so far, the plan presented herein may be considered mature but still provisional. Nevertheless, it serves well to exploit research findings regarding the conjunction of the suggested equipment to the local grid which is the key delivery of the paper. To account for possible changes in the locations or the thematic properties of stations, an Excel-based monitoring tool has already been shared among the interested bodies for immediate exchange of alternative planning suggestions in the areas of their responsibility. According to the plan, monitoring procedures will take place on a biannual basis starting in June 2021. The foreseen numbers of charging stations and EV parking spaces are summarized in Table 1. An overview of the suggested distribution of EV chargers is presented in Figure 3. The detailed thematic properties of each station are provided in Appendix A.

Table 1. Summary of charging stations and EV parking spaces.

\begin{tabular}{ccc}
\hline Vehicle & No. of Charging Stations & Number of Parking Spaces \\
\hline Passenger cars & 75 & 160 \\
\hline Taxis & 12 & 17 \\
\hline Two-wheelers & 6 & 24 \\
\hline Buses & 25 & 35 \\
\hline Passenger cars of people with disabilities & 4 & 4 \\
\hline Total & $\mathbf{1 2 2}$ & $\mathbf{2 4 0}$ \\
\hline
\end{tabular}




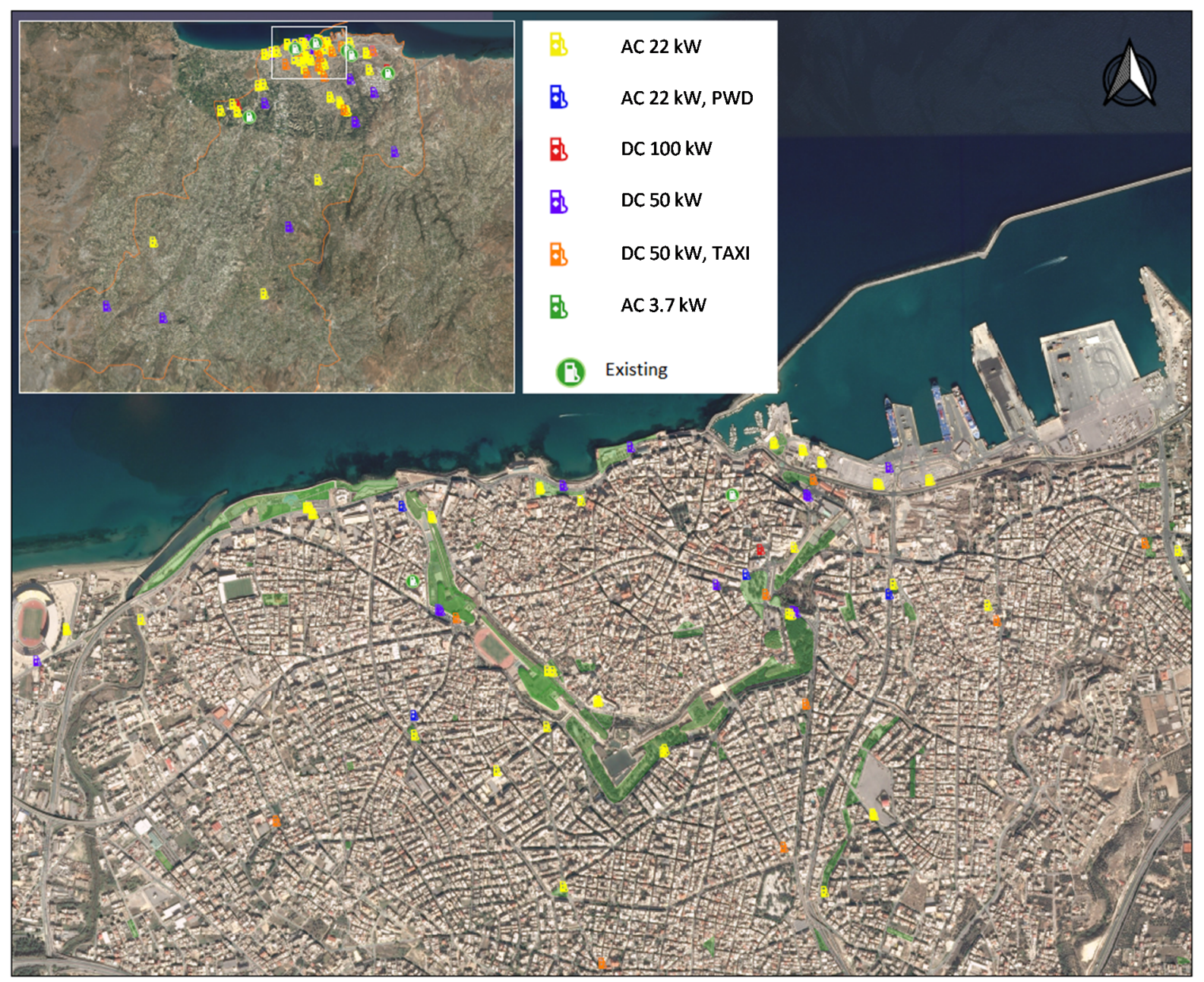

Figure 3. Overview of the suggested spatial distribution of EV chargers.

\section{Methods for Determining the Energy Needs of Electric Vehicles}

Generally, the EVs' final energy needs depend on several parameters. As energy needs, we consider the power that an electric car needs to recharge its battery and meet its daily needs. An extensive study is required for assessing the energy needs, which depend on the vehicle class, vehicle technology (battery capacity and vehicle consumption), as well as daily routes that the driver has.

More precisely, the aggregate demand depends mainly on the number of electric vehicles in circulation, the level of charge that each driver chooses for their vehicle and the charging strategy that each driver chooses to follow (controlled charging which takes place at a specific time during the day or uncontrolled charging where each driver charges whenever they want).

\subsection{Assessment of the EV Fleet}

Three electric vehicle penetration scenarios were studied, as depicted in Figure 4, considering a baseline for 2020 of 900 new cars registrations with 3\% of them being EVs:

1. A conservative scenario of low penetration of EVs that is more likely to happen, represented by a $5 \%$ annual rate of increment of EV sales.

2. A more optimistic penetration scenario represented by a $15 \%$ annual rate of increment of EV sales.

3. An aggressive scenario of extensive electric vehicles penetration represented by a $35 \%$ annual rate of increment of EV sales. 


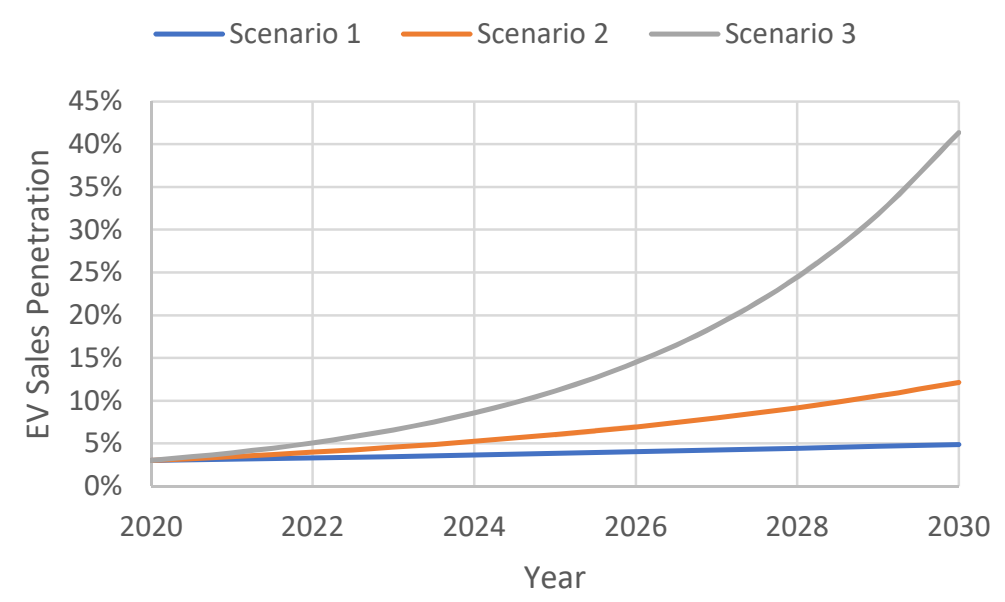

Figure 4. Scenarios of the EV penetration level in annual sales.

\subsection{Electric Vehicles Classification}

As defined, electric vehicles are divided into four classes: passenger cars, taxis, twowheelers, and buses. The evolution of mobility in smart cities has been studied extensively [18-20].

\subsection{Electric Vehicles' Charging Category}

As predefined, electric vehicles can be charged to several levels, considering the electric current needs and type (single-phase and/or three-phase charging), as shortly shown in Tables 1 and 2 and analytically in Appendix A.

Table 2. Three types of electric vehicles charging.

\begin{tabular}{cccc}
\hline & & \multicolumn{2}{c}{ Charging Voltage } \\
& & Single-Phase 230V & Three-Phase 400V \\
\cline { 3 - 3 } & $16 \mathrm{~A}$ & $3.70 \mathrm{~kW}$ & $11.00 \mathrm{~kW}$ \\
\cline { 3 - 4 } Charging & $32 \mathrm{~A}$ & $7.40 \mathrm{~kW}$ & $22.00 \mathrm{~kW}$ \\
current & $100 \mathrm{~A}$ & - & $50.00 \mathrm{~kW}$ \\
\cline { 3 - 4 } & $160 \mathrm{~A}$ & - & $100.00 \mathrm{~kW}$ \\
\hline
\end{tabular}

\subsection{Distribution of the Daily Distance Traveled}

Regarding the distances traveled by electric vehicles both on a regular day and on a weekend, it was considered that the daily distance traveled by each vehicle follows normal distribution.

\subsection{Charging Losses}

Charging losses are losses that come out from alternating current conversion to direct current to charge the car or vice versa, depending each time on the use of power electronics. It is considered that charging losses are $6 \%$ of the total demand.

\subsection{Charging Strategy}

A very important factor in calculating the final demand curve of electric vehicles is the charging strategy [21-23]. For this reason, two different approaches were created depending on the charging strategy that each driver can follow.

- $\quad$ Approach 1: uncontrolled charging.

- Approach 2: controlled charging.

All the parameters mentioned so far do not depend on how an electric vehicle owner may decide to charge their vehicle and apply to all approaches as they relate to the energy 
needs of an electric vehicle. The time slot is a new unit of time that is defined in the two charging strategies for greater accuracy and lasts ten minutes. The time slot is the shortest period during which the external environment is considered unchanged. Therefore, a possible connection or disconnection of a vehicle charger or the beginning or end of a vehicle's charging will be perceived as the number of these time slots. During this time, the charging is uninterrupted at a constant power.

\subsubsection{Approach 1: Uncontrolled Charging}

In this charging procedure, each driver charges their vehicle, approximately whenever he decides, and two daily demand patterns are followed, one for the weekdays and one for the weekend. More precisely, for the weekdays, it is considered that EV drivers charge their cars within two main time periods, firstly when they go to their offices, starting at 7 am and ending at $5 \mathrm{pm}$, and secondly when they move along and around the city, starting at $4 \mathrm{pm}$ and ending by $1 \mathrm{am}$. For the weekend, there is a specific pattern. Generally, it is clear that the demand patterns can be reevaluated with the measured data in the near future to represent more accurately the real charging demand.

The following variables are used for each vehicle category and charge level:

- FC: the final consumption of each vehicle is calculated by multiplying the total distance traveled (TL) during the day by the average energy consumption (AEC) of each vehicle type and dividing it by efficiency (EFF):

$$
\mathrm{FC}=\mathrm{TL} \cdot \mathrm{AEC} / \mathrm{EFF} \mathrm{kWh}
$$

- ST: the starting time of vehicle charging. This parameter varies for each vehicle and follows normal distribution, with an average value at the time when the majority of drivers return home from work.

- $\quad \mathrm{CT}$ : the charging time of each vehicle. It is calculated by dividing the final consumption (FC) by the charging level (CL) at which each vehicle charges.

$$
\mathrm{CT}=\mathrm{FC} / \mathrm{CL} \mathrm{h}
$$

Consequently, estimating the total number of vehicles (Figure 5), the numbers of vehicles belonging to each category, as well as the time of connection and disconnection of vehicles, the final daily EV demand curves are extracted.

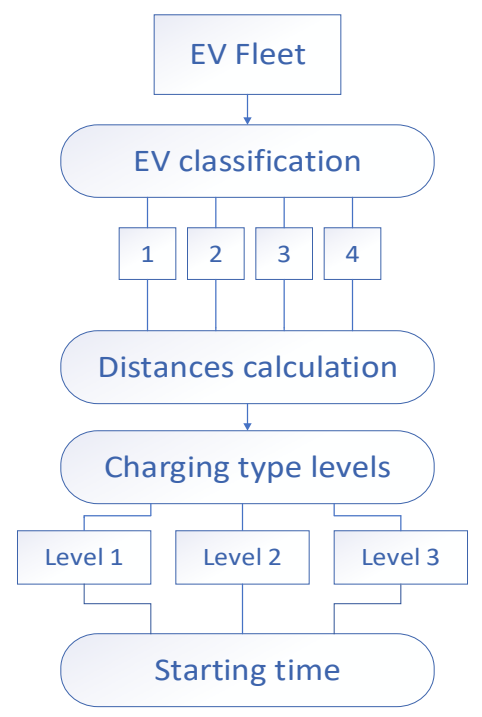

Figure 5. Approach 1 for daily EV demand curve calculation. 


\subsubsection{Approach 2: Controlled Charging}

The parameters used in approach 2 are identical to those of approach 1, with the only difference that in approach 2, the parameter that provides the starting time of charging for EVs is calculated after the current power flow state estimation, as it is depicted in Figure 6. This should lead to a more effective charging strategy for the local grid.

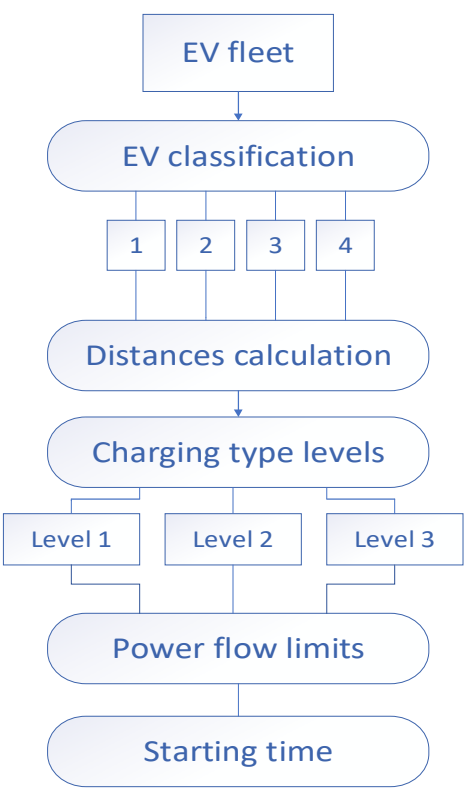

Figure 6. Approach 2 for daily EV demand curve calculation.

Generally, in this charging strategy, the starting time for an EV charge is currently postponed and shifted by half an hour each time that the corresponding MV/HV substation reaches a predefined limit.

The following graphs in Figures 7 and 8 depict two patterns for EV load demands during their charging state in 2030.

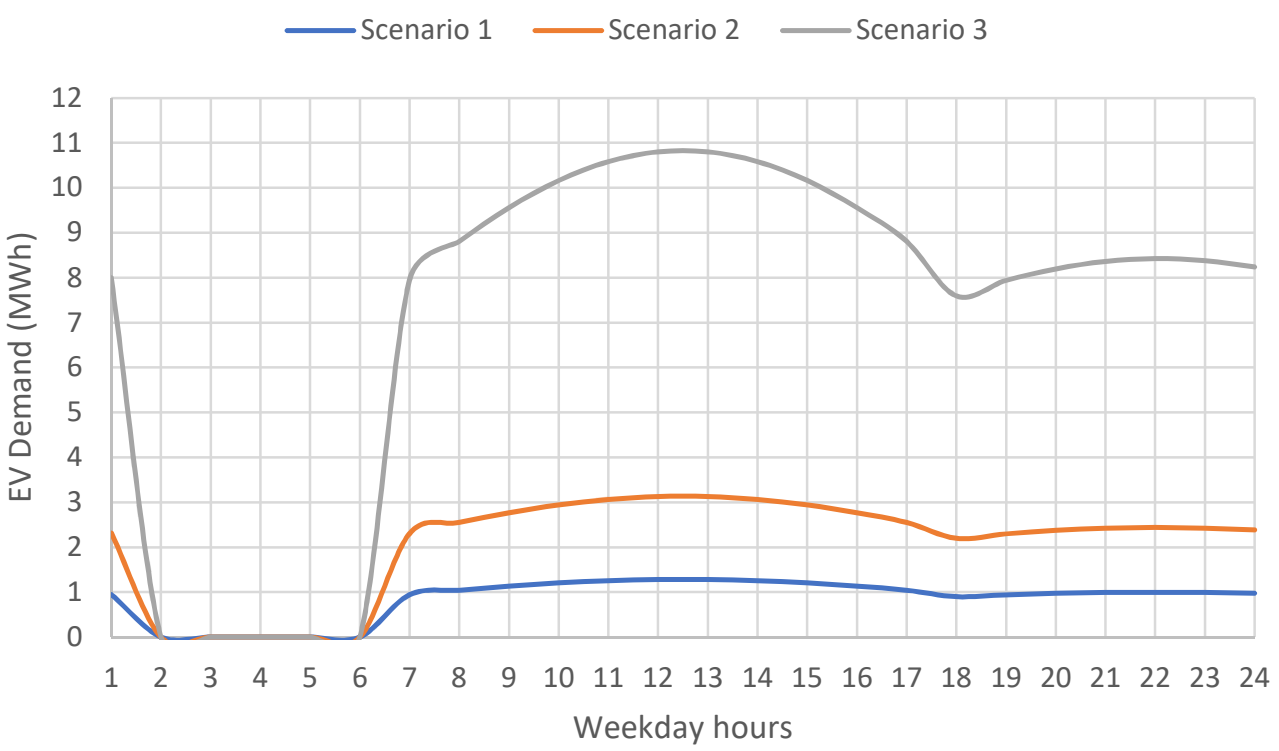

Figure 7. Daily EV demand curve calculation for a weekday. 


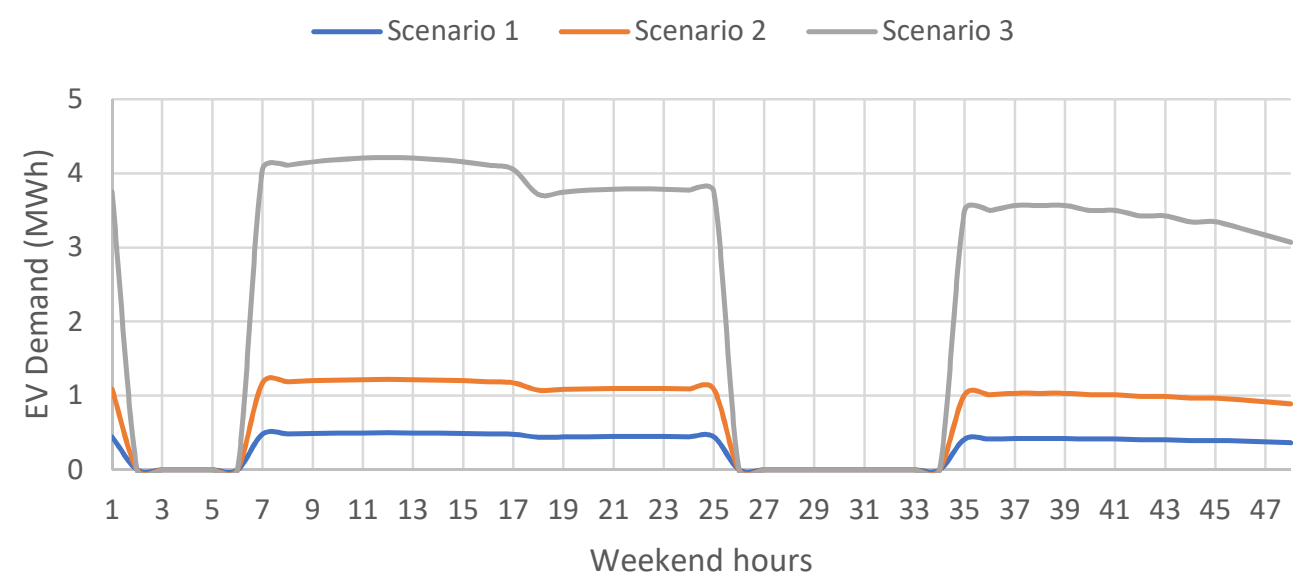

Figure 8. EV demand curve calculation for the weekend.

\section{Results}

Powerworld simulator version 21 was used to simulate the medium voltage distribution system of the city under all the examined scenarios and assess the required power flows. The extracted results of these power flows were fed to the second approach to optimize the charging strategy.

The results of the estimated additional power demand caused by the charging of EVs at the three (3) City's high-voltage substations $(150 \mathrm{kV} / 20 \mathrm{kV})$, as they are presented in Table 3, are based on two comparative methods presented in the following subsections. The total installed capacity of the three substations is $350 \mathrm{MVA}$. In order to consider the worstcase scenario, the installed capacity of the transformers without ventilation is estimated to be 297.5 MVA.

Table 3. Features of the three HV/MV substations in the city.

\begin{tabular}{ccc}
\hline Substation & Installed Capacity (MVA) & Current Peak Power Demand (MW) \\
\hline Heraklion I & $2 \times 50$ & 62 \\
\hline Heraklion II & $3 \times 50$ & 86 \\
\hline Heraklion III & $2 \times 50$ & 42 \\
\hline Total & $\mathbf{3 5 0}$ & $\mathbf{1 9 0}$ \\
\hline
\end{tabular}

A. Comparison of the substations' capacity and the peak demand

This method is simply based upon the comparison of the installed capacity and the peak demand for each substation. The balance of the two values gives the limitations of the additional power demand to estimate the hosting capacity for EVs in the power grid. More precisely, it is based on the installed capacity of the substation transformers along with the substation's peak demand (average hourly). In this case, the worst-case scenario is considered with the transformers to operate with no ventilation, taking into account their lowest installed capacity, whereas the corresponding power factor is considered to be 0.95 .

B. The case of transformer fault

This method includes capacity estimation in case of a complete transformer loss. The values that are considered are the remaining installed capacity of the substation's transformers and the substation's peak demand (average hourly). Therefore, the N-1 criterion for a substation can be evaluated. The possibility of a wide range of charging processes, from very slow to very fast, is examined in the produced results. As mentioned in the previous section, a slow full charge at $3.7 \mathrm{~kW} / \mathrm{h}$ for a typical battery of $22 \mathrm{kWh}$ is considered to last about $6 \mathrm{~h}$, whereas a fast full charge at $50 \mathrm{~kW} / \mathrm{h}-10-30 \mathrm{~min}$, with $100 \mathrm{~kW} / \mathrm{h}$ in specific vehicles. 
At this point, previous research [13] about the contribution of local RES production to power generation and the corresponding amount of EV hosting in the local island's power system should be mentioned. If the total capacity of RES, currently at $300 \mathrm{MW}$, is exploited based on the calculations of the total capacity of the local grid, the number of charging EVs that could simultaneously penetrate the power system of Crete amounts to 131,324 slowcharging EVs or 9718 fast-charging EVs. However, quite often, RES do not participate so much in meeting the demand since, unfortunately, the annual peak demand takes place when the wind power is rather low and sometimes in the early evening hours when there is no sunshine. In such a case, the number of EVs that could simultaneously be charged is dramatically decreased to 32,133 slow-charging vehicles or 2378 fast-charging vehicles.

A. Results of application of the first method

As it was previously mentioned, the total installed capacity of the three substations is $350 \mathrm{MVA}$, whereas the installed capacity of the transformers without ventilation is estimated to be 297.5 MVA. As a result, the EV hosting capacity in the transformers of the City varies from 4196 to 6993 vehicles due to different charging profiles and types.

The EV capacity in the transformers of each substation is as shown in Table 3. This is the maximum achievable capacity provided that reconfiguration of the distribution grid in each substation can be made. Thus, lack of capacity in one of the substations in each prefecture could be mitigated by serving its feeders by a nearby substation. However, such a scenario can be rather optimistic and requires extensive research and additional investments in the distribution grid. The number of EVs that could be charged by each substation without neither additional investment in the distribution grid nor investment in distributed generation is described in Table 4.

Table 4. Transformers' hosting capacity for EVs per substation.

\begin{tabular}{ccc}
\hline Substation & Average Available Power (MW) & EV Hosting Range \\
\hline Heraklion I & $2 \times 7.4$ & $802-1335$ \\
\hline Heraklion II & $3 \times 9.1$ & $1532-2554$ \\
\hline Heraklion III & $2 \times 17.2$ & $1862-3104$ \\
\hline Total & $\mathbf{7 7 . 5}$ & $\mathbf{4 1 9 6 - 6 9 9 3}$ \\
\hline
\end{tabular}

B. Results of application of the second method

The results of the second method provided capacity estimation of EVs for each substation of the city in case one of its transformers is out of service. Table 5 presents the results, where the available charging capacity varies from 2316 to 3862 vehicles. Clearly, under the $\mathrm{N}-1$ criterion, much fewer EVs can be charged. A graphical comparison of the capacity per substation is shown in Figure 9 for all the cases studied.

Table 5. Transformers' hosting capacity of EVs per substation.

\begin{tabular}{ccc}
\hline Substation & Average Available Power (MW) & EV Hosting Range \\
\hline Heraklion I & $2 \times 7.4$ & $400-668$ \\
\hline Heraklion II & $3 \times 9.1$ & $985-1642$ \\
\hline Heraklion III & $2 \times 17.2$ & $931-1552$ \\
\hline Total & $\mathbf{7 7 . 5}$ & $\mathbf{2 3 1 6 - 3 8 6 2}$ \\
\hline
\end{tabular}




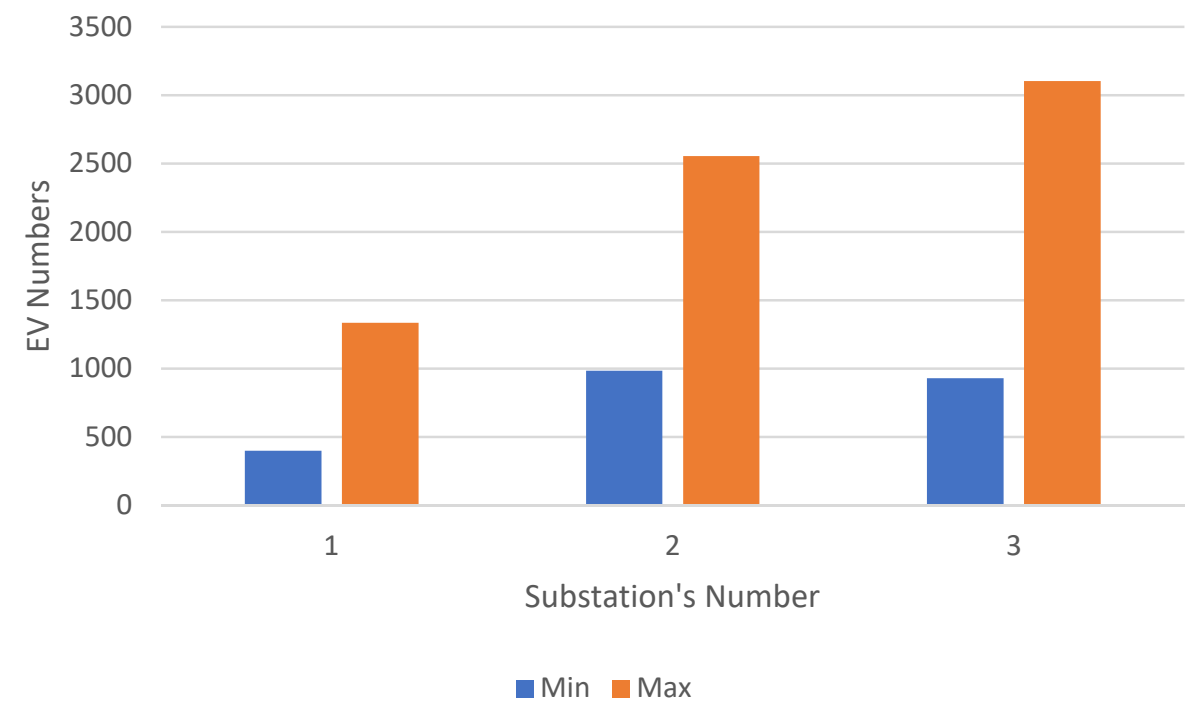

Figure 9. EV hosting capacity range per substation.

\section{Conclusions}

The power supply performance and reliability along with the potential impacts of uncontrolled EV charging on system operation is an issue for any utility worldwide, especially for island power systems. Both a significant increase of the total system's peak demand and a considerable change of the loading of HV/MV substations are expected. Focusing on the cities, which are coping with unprecedented changes, national strategies are employed to support electromobility, beside resilience and sustainability goals. Such a strategic plan has already been enacted by the Hellenic Ministry of Environment and Energy funding the municipalities to perform siting and sizing plans for electric vehicle chargers. In this paper, the final study of this strategic plan for the municipality of Heraklion in Crete is used as a case study to investigate the effect of EV chargers on the operation of the Cretan power system. Their selected siting points are evaluated by performing a power flow analysis using the Powerworld Simulator software at the level of the City's distribution system. The EVs' charging demand is aggregated at each $20 \mathrm{kV} / 150 \mathrm{kV}$ substation of the metropolitan grid and the effect on substation loading is investigated and assessed.

In this paper, the first step of an extensive research that will be continued for the next years, focusing on the constant optimization of a specific urban electromobility plan, was carried out. More precisely, a method was used to estimate the hosting capacity of charging EVs in the power grid of the City of Heraklion. Data processing that is based on the existing substations and the peak demands showed that 3862 slow-charging EVs could simultaneously be charged under an average charging profile by the city's grid infrastructure even at the N-1 criterion of all the transformers. On the other hand, the number for fast charging is considerably lower at 2316 EVs. At the peak demand, when all the transformers work properly, the grid can host simultaneously 6993 EVs, mainly in the slow- and medium-charge modes.

Consequently, additional research and advanced charging control strategies need to consider congestion in the distribution grid (MV and LV). Moreover, extensive fast charging should be avoided to minimize the risk of sudden stress on the city's grid. Control strategies could mitigate the need for upscale substation equipment since not all the vehicles will charge simultaneously, reduce the amount of investment, or even postpone reinforcements in case of considerable penetration levels [21,22]. The first step in this direction could be the implementation of a sequential charging pattern for the vehicles that are connected to the grid. In this way, the number of vehicles that could be charged over an hour can be doubled. 
The next step of this research is the examination of siting and sizing of the several EV chargers at the primary (medium voltage) and secondary (low voltage) level of the distribution grid through extensive power flow analysis. The previous results should be combined with the modern optimization techniques, based on artificial intelligence, to enhance the overall operation of the city's grid.

Another step in this direction could be the application of smart charging limitations, especially when there are high power demands or in cases where the networks operate close to their limits or to preserve equipment. The control strategies could also maximize the penetration of RES and combine charging when RES production is high. Such solutions could help increase the penetration of EVs on the island of Crete mitigating the impact of EVs on the generation and transmission network equipment.

To conclude, extensive future research should be carried out considering the total electrification of the local means of public transportation, e.g., electric buses, as well as the electrification of the city's international port and the increased dispersed generation, mainly through local prosumers. All the abovementioned aspects should lead to a sustainable and smart city evolution plan.

Author Contributions: Conceptualization, E.K., A.T. and G.S.; methodology, A.T., A.P., C.C., G.S. and P.Z.; software, E.K. and A.P.; validation, A.T., C.C. and G.S.; formal analysis, E.K.; investigation, A.T., C.C. and G.S.; resources, A.P., C.C., E.F., G.S. and P.Z.; data curation, E.K. and A.P.; writing—original draft preparation, E.K. and G.S.; writing-review and editing, E.K. and G.S.; visualization, E.K. and G.S.; supervision, E.K. and E.F.; project administration, E.K., E.F., G.S. and P.Z. All authors have read and agreed to the published version of the manuscript.

Funding: This research received no external funding.

Institutional Review Board Statement: Not applicable.

Informed Consent Statement: Not applicable.

Acknowledgments: The authors would like to thank the municipality of Heraklion for providing all the necessary information of the provisional location plan of EV charging stations.

Conflicts of Interest: The authors declare no conflict of interest. 


\section{Appendix A}

Table A1. Features of the suggested EV charging stations in the municipality of Heraklion.

\begin{tabular}{|c|c|c|c|c|c|c|}
\hline No. * & $\begin{array}{l}\text { Geographical Coordinates, } \\
\text { Latitude/Longitude }\end{array}$ & Primary Vehicles Charged & Charger Type & No. of Parking Spaces & Installation & $\begin{array}{c}\text { No. of Spaces and } \\
\text { Indicative Dimensions }\end{array}$ \\
\hline 1 & $35^{\circ} 20^{\prime} 26.17^{\prime \prime} \mathrm{B} / 25^{\circ} 7^{\prime} 3.87^{\prime \prime} \mathrm{A}$ & Passenger (single-family) cars & AC $22 \mathrm{~kW}$ & 2 & Ground-mounted & $\begin{array}{l}\text { 1.1: } 2.5 \mathrm{~m} \times 5 \mathrm{~m} \\
\text { 1.2: } 2.5 \mathrm{~m} \times 5 \mathrm{~m}\end{array}$ \\
\hline 2 & $35^{\circ} 20^{\prime} 26.17^{\prime \prime} \mathrm{B} / 25^{\circ} 7^{\prime} 4.13^{\prime \prime} \mathrm{A}$ & Passenger (single-family) cars & AC $22 \mathrm{~kW}$ & 2 & Ground-mounted & $\begin{array}{l}\text { 2.1: } 2.5 \mathrm{~m} \times 5 \mathrm{~m} \\
\text { 2.2: } 2.5 \mathrm{~m} \times 5 \mathrm{~m}\end{array}$ \\
\hline 3 & $35^{\circ} 20^{\prime} 26.19^{\prime \prime} \mathrm{B} / 25^{\circ} 7^{\prime} 4.40^{\prime \prime} \mathrm{A}$ & Passenger (single-family) cars & AC $22 \mathrm{~kW}$ & 2 & Ground-mounted & $\begin{array}{l}\text { 3.1: } 2.5 \mathrm{~m} \times 5 \mathrm{~m} \\
3.2: 2.5 \mathrm{~m} \times 5 \mathrm{~m}\end{array}$ \\
\hline 5 & $35^{\circ} 20^{\prime} 25.43^{\prime \prime} \mathrm{B} / 25^{\circ} 7^{\prime} 4.95^{\prime \prime} \mathrm{A}$ & Passenger (single-family) cars & AC $22 \mathrm{~kW}$ & 2 & Ground-mounted & $\begin{array}{l}\text { 5.1: } 2.5 \mathrm{~m} \times 5 \mathrm{~m} \\
\text { 5.2: } 2.5 \mathrm{~m} \times 5 \mathrm{~m}\end{array}$ \\
\hline 6 & $35^{\circ} 20^{\prime} 25.42^{\prime \prime} \mathrm{B} / 25^{\circ} 7^{\prime} 4.70^{\prime \prime} \mathrm{A}$ & Passenger (single-family) cars & AC $22 \mathrm{~kW}$ & 2 & Ground-mounted & $\begin{array}{l}\text { 6.1: } 2.5 \mathrm{~m} \times 5 \mathrm{~m} \\
\text { 6.2: } 2.5 \mathrm{~m} \times 5 \mathrm{~m}\end{array}$ \\
\hline 7 & $35^{\circ} 20^{\prime} 33.19^{\prime \prime} \mathrm{B} / 25^{\circ} 7^{\prime} 52.63^{\prime \prime} \mathrm{A}$ & Passenger (single-family) cars & Fast charger, DC $50 \mathrm{~kW}$ & 2 & Wall-mounted & $\begin{array}{l}\text { 7.1: } 2.5 \mathrm{~m} \times 5 \mathrm{~m} \\
\text { 7.2: } 2.5 \mathrm{~m} \times 5 \mathrm{~m}\end{array}$ \\
\hline 9 & $35^{\circ} 20^{\prime} 28.24^{\prime \prime} \mathrm{B} / 25^{\circ} 7^{\prime} 38.97^{\prime \prime} \mathrm{A}$ & Passenger (single-family) cars & AC $22 \mathrm{~kW}$ & 2 & Wall-mounted & $\begin{array}{l}\text { 9.1: } 2.5 \mathrm{~m} \times 5 \mathrm{~m} \\
\text { 9.2: } 2.5 \mathrm{~m} \times 5 \mathrm{~m}\end{array}$ \\
\hline 10 & $35^{\circ} 20^{\prime} 28.13^{\prime \prime} \mathrm{B} / 25^{\circ} 7^{\prime} 38.91^{\prime \prime} \mathrm{A}$ & Passenger (single-family) cars & AC $22 \mathrm{~kW}$ & 2 & Wall-mounted & $\begin{array}{l}\text { 10.1: } 2.5 \mathrm{~m} \times 5 \mathrm{~m} \\
\text { 10.2: } 2.5 \mathrm{~m} \times 5 \mathrm{~m}\end{array}$ \\
\hline 11 & $35^{\circ} 20^{\prime} 27.42^{\prime \prime} \mathrm{B} / 25^{\circ} 9^{\prime} 29.76^{\prime \prime} \mathrm{A}$ & Passenger (single-family) cars & AC $22 \mathrm{~kW}$ & 2 & Ground-mounted & $\begin{array}{l}\text { 11.1: } 2.5 \mathrm{~m} \times 5 \mathrm{~m} \\
11.2: 2.5 \mathrm{~m} \times 5 \mathrm{~m}\end{array}$ \\
\hline 12 & $35^{\circ} 19^{\prime} 58.06^{\prime \prime} \mathrm{B} / 25^{\circ} 7^{\prime} 19.70^{\prime \prime} \mathrm{A}$ & Passenger (single-family) cars & AC $22 \mathrm{~kW}$ & 2 & Ground-mounted & $\begin{array}{l}\text { 12.1: } 2.5 \mathrm{~m} \times 5 \mathrm{~m} \\
\text { 12.2: } 2.5 \mathrm{~m} \times 5 \mathrm{~m}\end{array}$ \\
\hline 13 & $35^{\circ} 20^{\prime} 32.57^{\prime \prime} \mathrm{B} / 25^{\circ} 8^{\prime} 18.41^{\prime \prime} \mathrm{A}$ & Passenger (single-family) cars & AC $22 \mathrm{~kW}$ & 2 & Ground-mounted & $\begin{array}{l}\text { 13.1: } 2.5 \mathrm{~m} \times 5 \mathrm{~m} \\
\text { 13.2: } 2.5 \mathrm{~m} \times 5 \mathrm{~m}\end{array}$ \\
\hline
\end{tabular}


Table A1. Cont.

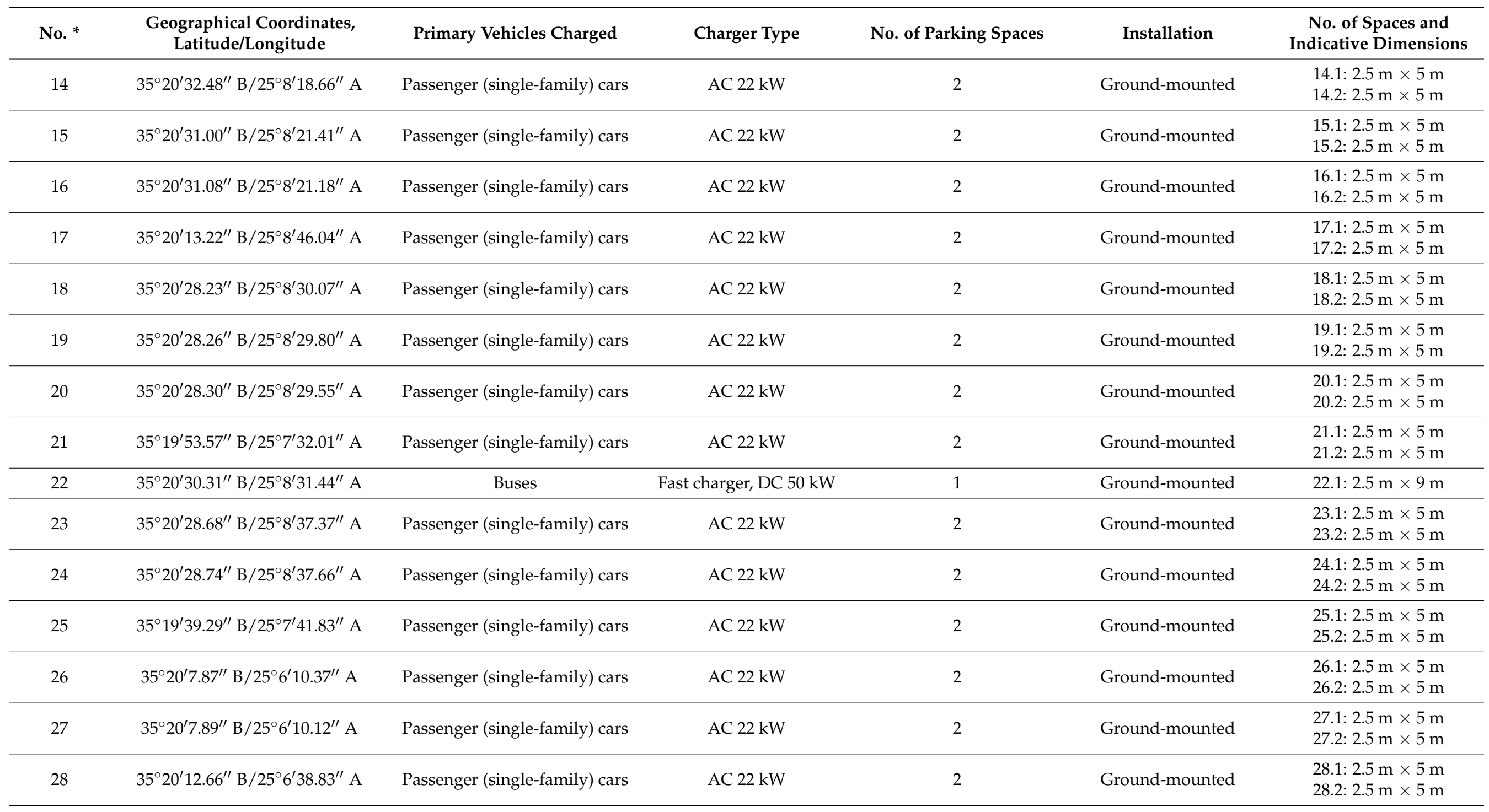


Table A1. Cont.

\begin{tabular}{|c|c|c|c|c|c|c|}
\hline No. * & $\begin{array}{l}\text { Geographical Coordinates, } \\
\text { Latitude/Longitude }\end{array}$ & Primary Vehicles Charged & Charger Type & No. of Parking Spaces & Installation & $\begin{array}{c}\text { No. of Spaces and } \\
\text { Indicative Dimensions }\end{array}$ \\
\hline 29 & $35^{\circ} 20^{\prime} 7.72^{\prime \prime} \mathrm{B} / 25^{\circ} 6^{\prime} 11.60^{\prime \prime} \mathrm{A}$ & Passenger (single-family) cars & AC $22 \mathrm{~kW}$ & 2 & Ground-mounted & $\begin{array}{l}\text { 29.1: } 2.5 \mathrm{~m} \times 5 \mathrm{~m} \\
\text { 29.2: } 2.5 \mathrm{~m} \times 5 \mathrm{~m}\end{array}$ \\
\hline 30 & $35^{\circ} 19^{\prime} 7.75^{\prime \prime} \mathrm{B} / 25^{\circ} 5^{\prime} 55.03^{\prime \prime} \mathrm{A}$ & Passenger (single-family) cars & AC $22 \mathrm{~kW}$ & 2 & Ground-mounted & $\begin{array}{l}\text { 30.1: } 2.5 \mathrm{~m} \times 5 \mathrm{~m} \\
\text { 30.2: } 2.5 \mathrm{~m} \times 5 \mathrm{~m}\end{array}$ \\
\hline 31 & $35^{\circ} 20^{\prime} 7.69^{\prime \prime} \mathrm{B} / 25^{\circ} 6^{\prime} 23.08^{\prime \prime} \mathrm{A}$ & Buses & Fast charger, DC 50 kW & 1 & Ground-mounted & 31.1: $2.5 \mathrm{~m} \times 9 \mathrm{~m}$ \\
\hline 32 & $35^{\circ} 20^{\prime} 11.48^{\prime \prime} \mathrm{B} / 25^{\circ} 6^{\prime} 27.56^{\prime \prime} \mathrm{A}$ & Passenger (single-family) cars & AC $22 \mathrm{~kW}$ & 2 & Ground-mounted & $\begin{array}{l}\text { 32.1: } 2.5 \mathrm{~m} \times 5 \mathrm{~m} \\
\text { 32.2: } 2.5 \mathrm{~m} \times 5 \mathrm{~m}\end{array}$ \\
\hline 33 & $35^{\circ} 20^{\prime} 11.69^{\prime \prime} \mathrm{B} / 25^{\circ} 6^{\prime} 27.61^{\prime \prime} \mathrm{A}$ & Passenger (single-family) cars & AC $22 \mathrm{~kW}$ & 2 & Ground-mounted & $\begin{array}{l}\text { 33.1: } 2.5 \mathrm{~m} \times 5 \mathrm{~m} \\
\text { 33.2: } 2.5 \mathrm{~m} \times 5 \mathrm{~m}\end{array}$ \\
\hline 34 & $35^{\circ} 20^{\prime} 24.77^{\prime \prime} \mathrm{B} / 25^{\circ} 7^{\prime} 22.76^{\prime \prime} \mathrm{A}$ & Passenger (single-family) cars & AC $22 \mathrm{~kW}$ & 2 & Ground-mounted & $\begin{array}{l}34.1: 2.5 \mathrm{~m} \times 5 \mathrm{~m} \\
34.2: 2.5 \mathrm{~m} \times 5 \mathrm{~m}\end{array}$ \\
\hline 35 & $35^{\circ} 20^{\prime} 24.96^{\prime \prime} \mathrm{B} / 25^{\circ} 7^{\prime} 22.61^{\prime \prime} \mathrm{A}$ & Passenger (single-family) cars & AC $22 \mathrm{~kW}$ & 2 & Ground-mounted & $\begin{array}{l}\text { 35.1: } 2.5 \mathrm{~m} \times 5 \mathrm{~m} \\
\text { 35.2: } 2.5 \mathrm{~m} \times 5 \mathrm{~m}\end{array}$ \\
\hline 36 & $35^{\circ} 20^{\prime} 1.87^{\prime \prime} \mathrm{B} / 25^{\circ} 7^{\prime} 47.12^{\prime \prime} \mathrm{A}$ & Passenger (single-family) cars & $\mathrm{AC} 22 \mathrm{~kW}$ & 2 & Wall-mounted & $\begin{array}{l}\text { 36.1: } 2.5 \mathrm{~m} \times 5 \mathrm{~m} \\
\text { 36.2: } 2.5 \mathrm{~m} \times 5 \mathrm{~m}\end{array}$ \\
\hline 37 & $35^{\circ} 20^{\prime} 1.90^{\prime \prime} \mathrm{B} / 25^{\circ} 7^{\prime} 47.30^{\prime \prime} \mathrm{A}$ & Passenger (single-family) cars & $\mathrm{AC} 22 \mathrm{~kW}$ & 2 & Wall-mounted & $\begin{array}{l}\text { 37.1: } 2.5 \mathrm{~m} \times 5 \mathrm{~m} \\
\text { 37.2: } 2.5 \mathrm{~m} \times 5 \mathrm{~m}\end{array}$ \\
\hline 38 & $35^{\circ} 20^{\prime} 1.94^{\prime \prime} \mathrm{B} / 25^{\circ} 7^{\prime} 47.48^{\prime \prime} \mathrm{A}$ & Passenger (single-family) cars & AC $22 \mathrm{~kW}$ & 2 & Wall-mounted & $\begin{array}{l}\text { 38.1: } 2.5 \mathrm{~m} \times 5 \mathrm{~m} \\
\text { 38.2: } 2.5 \mathrm{~m} \times 5 \mathrm{~m}\end{array}$ \\
\hline 39 & $35^{\circ} 18^{\prime} 35.26^{\prime \prime} \mathrm{B} / 25^{\circ} 9^{\prime} 3.51^{\prime \prime} \mathrm{A}$ & Passenger (single-family) cars & AC $22 \mathrm{~kW}$ & 2 & Ground-mounted & $\begin{array}{l}\text { 39.1: } 2.5 \mathrm{~m} \times 5 \mathrm{~m} \\
\text { 39.2: } 2.5 \mathrm{~m} \times 5 \mathrm{~m}\end{array}$ \\
\hline 40 & $35^{\circ} 19^{\prime} 23.81^{\prime \prime} \mathrm{B} / 25^{\circ} 8^{\prime} 28.44^{\prime \prime} \mathrm{A}$ & Taxis & Fast charger, DC 50 kW & 1 & Ground-mounted & 40.1: $2.5 \mathrm{~m} \times 5 \mathrm{~m}$ \\
\hline 41 & $35^{\circ} 20^{\prime} 26.86^{\prime \prime} \mathrm{B} / 25^{\circ} 8^{\prime} 19.29^{\prime \prime} \mathrm{A}$ & Buses & Fast charger, DC 50 kW & 2 & Ground-mounted & $\begin{array}{l}\text { 41.1: } 3 \mathrm{~m} \times 14 \mathrm{~m} \\
\text { 41.2: } 3 \mathrm{~m} \times 14 \mathrm{~m}\end{array}$ \\
\hline 42 & $35^{\circ} 20^{\prime} 27.01^{\prime \prime} \mathrm{B} / 25^{\circ} 8^{\prime} 19.04^{\prime \prime} \mathrm{A}$ & Buses & Fast charger, DC 50 kW & 2 & Ground-mounted & $\begin{array}{l}\text { 42.1: } 3 \mathrm{~m} \times 14 \mathrm{~m} \\
42.2: 3 \mathrm{~m} \times 14 \mathrm{~m}\end{array}$ \\
\hline 43 & $35^{\circ} 20^{\prime} 13.48^{\prime \prime} \mathrm{B} / 25^{\circ} 7^{\prime} 23.54^{\prime \prime} \mathrm{A}$ & Buses & Fast charger, DC 50 kW & 2 & Ground-mounted & $\begin{array}{l}\text { 43.1: } 3 \mathrm{~m} \times 14 \mathrm{~m} \\
\text { 43.2: } 3 \mathrm{~m} \times 14 \mathrm{~m}\end{array}$ \\
\hline
\end{tabular}


Table A1. Cont.

\begin{tabular}{|c|c|c|c|c|c|c|}
\hline No. * & $\begin{array}{l}\text { Geographical Coordinates, } \\
\text { Latitude/Longitude }\end{array}$ & Primary Vehicles Charged & Charger Type & No. of Parking Spaces & Installation & $\begin{array}{l}\text { No. of Spaces and } \\
\text { Indicative Dimensions }\end{array}$ \\
\hline 44 & $35^{\circ} 20^{\prime} 13.36^{\prime \prime} \mathrm{B} / 25^{\circ} 7^{\prime} 23.84^{\prime \prime} \mathrm{A}$ & Buses & Fast charger, DC 50 kW & 2 & Ground-mounted & $\begin{array}{l}\text { 44.1: } 3 \mathrm{~m} \times 14 \mathrm{~m} \\
44.2: 3 \mathrm{~m} \times 14 \mathrm{~m}\end{array}$ \\
\hline 45 & $35^{\circ} 20^{\prime} 20.44^{\prime \prime} \mathrm{B} / 25^{\circ} 8^{\prime} 11.96^{\prime \prime} \mathrm{A}$ & Buses & Fast charger, DC $100 \mathrm{~kW}$ & 2 & Ground-mounted & $\begin{array}{l}\text { 45.1: } 3 \mathrm{~m} \times 14 \mathrm{~m} \\
45.2: 3 \mathrm{~m} \times 14 \mathrm{~m}\end{array}$ \\
\hline 46 & $35^{\circ} 20^{\prime} 12.75^{\prime \prime} \mathrm{B} / 25^{\circ} 8^{\prime} 16.80^{\prime \prime} \mathrm{A}$ & Buses + passenger cars & Fast charger, DC 50 kW & 2 & Ground-mounted & $\begin{array}{l}\text { 46.1: } 3 \mathrm{~m} \times 14 \mathrm{~m} \\
46.2: 2.5 \mathrm{~m} \times 5 \mathrm{~m}\end{array}$ \\
\hline 48 & $35^{\circ} 17^{\prime} 56.55^{\prime \prime} \mathrm{B} / 25^{\circ} 9^{\prime} 39.90^{\prime \prime} \mathrm{A}$ & Buses + passenger cars & Fast charger, DC 50 kW & 2 & Ground-mounted & $\begin{array}{l}\text { 48.1: } 3 \mathrm{~m} \times 14 \mathrm{~m} \\
\text { 48.2: } 3 \mathrm{~m} \times 14 \mathrm{~m} \\
\text { 48.3: } 2.5 \mathrm{~m} \times 5 \mathrm{~m} \\
\text { 48.4: } 2.5 \mathrm{~m} \times 5 \mathrm{~m}\end{array}$ \\
\hline 49 & $35^{\circ} 17^{\prime} 56.56^{\prime \prime} \mathrm{B} / 25^{\circ} 9^{\prime} 39.98^{\prime \prime} \mathrm{A}$ & Buses + passenger cars & Fast charger, DC 50 kW & 2 & Ground-mounted & $\begin{array}{l}\text { 49.1: } 3 \mathrm{~m} \times 14 \mathrm{~m} \\
\text { 49.2: } 3 \mathrm{~m} \times 14 \mathrm{~m} \\
\text { 49.3: } 2.5 \mathrm{~m} \times 5 \mathrm{~m} \\
\text { 49.4: } 2.5 \mathrm{~m} \times 5 \mathrm{~m}\end{array}$ \\
\hline 50 & $35^{\circ} 20^{\prime} 11.23^{\prime \prime} \mathrm{B} / 25^{\circ} 10^{\prime} 22.28^{\prime \prime} \mathrm{A}$ & Buses + passenger cars & Fast charger, DC 50 kW & 2 & Ground-mounted & $\begin{array}{l}\text { 50.1: } 3 \mathrm{~m} \times 14 \mathrm{~m} \\
50.2: 3 \mathrm{~m} \times 14 \mathrm{~m}\end{array}$ \\
\hline 51 & $35^{\circ} 20^{\prime} 8.36^{\prime \prime} \mathrm{B} / 25^{\circ} 10^{\prime} 7.68^{\prime \prime} \mathrm{A}$ & Passenger (single-family) cars & AC $22 \mathrm{~kW}$ & 2 & Ground-mounted & $\begin{array}{l}\text { 51.1: } 2.5 \mathrm{~m} \times 5 \mathrm{~m} \\
\text { 51.2: } 2.5 \mathrm{~m} \times 5 \mathrm{~m}\end{array}$ \\
\hline 52 & $35^{\circ} 20^{\prime} 7.75^{\prime \prime} \mathrm{B} / 25^{\circ} 10^{\prime} 7.80^{\prime \prime} \mathrm{A}$ & Passenger (single-family) cars & AC $22 \mathrm{~kW}$ & 2 & Ground-mounted & $\begin{array}{l}\text { 52.1: } 2.5 \mathrm{~m} \times 5 \mathrm{~m} \\
\text { 52.2: } 2.5 \mathrm{~m} \times 5 \mathrm{~m}\end{array}$ \\
\hline 53 & $35^{\circ} 20^{\prime} 7.05^{\prime \prime} \mathrm{B} / 25^{\circ} 10^{\prime} 7.96^{\prime \prime} \mathrm{A}$ & Passenger (single-family) cars & $\mathrm{AC} 22 \mathrm{~kW}$ & 2 & Ground-mounted & $\begin{array}{l}\text { 53.1: } 2.5 \mathrm{~m} \times 5 \mathrm{~m} \\
\text { 53.2: } 2.5 \mathrm{~m} \times 5 \mathrm{~m}\end{array}$ \\
\hline 54 & $35^{\circ} 19^{\prime} 27.81^{\prime \prime} \mathrm{B} / 25^{\circ} 10^{\prime} 54.21^{\prime \prime} \mathrm{A}$ & Heavy-duty vehicles & Fast charger, DC $100 \mathrm{~kW}$ & 4 & Ground-mounted & $\begin{array}{l}\text { 54.1: } 3 \mathrm{~m} \times 14 \mathrm{~m} \\
\text { 54.2: } 3 \mathrm{~m} \times 14 \mathrm{~m} \\
\text { 54.3: } 2.5 \mathrm{~m} \times 5 \mathrm{~m} \\
\text { 54.4: } 2.5 \mathrm{~m} \times 5 \mathrm{~m}\end{array}$ \\
\hline
\end{tabular}


Table A1. Cont.

\begin{tabular}{|c|c|c|c|c|c|c|}
\hline No. * & $\begin{array}{l}\text { Geographical Coordinates, } \\
\text { Latitude/Longitude }\end{array}$ & Primary Vehicles Charged & Charger Type & No. of Parking Spaces & Installation & $\begin{array}{c}\text { No. of Spaces and } \\
\text { Indicative Dimensions }\end{array}$ \\
\hline 55 & $35^{\circ} 19^{\prime} 35.39^{\prime \prime} \mathrm{B} / 25^{\circ} 10^{\prime} 56.40^{\prime \prime} \mathrm{A}$ & Heavy-duty vehicles & Fast charger, DC $100 \mathrm{~kW}$ & 4 & Ground-mounted & $\begin{array}{l}\text { 55.1: } 3 \mathrm{~m} \times 14 \mathrm{~m} \\
\text { 55.2: } 3 \mathrm{~m} \times 14 \mathrm{~m} \\
\text { 55.3: } 2.5 \mathrm{~m} \times 5 \mathrm{~m} \\
\text { 55.4: } 2.5 \mathrm{~m} \times 5 \mathrm{~m}\end{array}$ \\
\hline 56 & $35^{\circ} 20^{\prime} 14.89^{\prime \prime} \mathrm{B} / 25^{\circ} 8^{\prime} 12.71^{\prime \prime} \mathrm{A}$ & Taxis & Fast charger, DC 50 kW & 2 & Ground-mounted & $\begin{array}{l}\text { 56.1: } 2.5 \mathrm{~m} \times 5 \mathrm{~m} \\
\text { 56.2: } 2.5 \mathrm{~m} \times 5 \mathrm{~m}\end{array}$ \\
\hline 58 & $35^{\circ} 20^{\prime} 20.64^{\prime \prime} \mathrm{B} / 25^{\circ} 9^{\prime} 9.77^{\prime \prime} \mathrm{A}$ & Taxis & Fast charger, DC $50 \mathrm{~kW}$ & 1 & Ground-mounted & 58.1: $2.5 \mathrm{~m} \times 5 \mathrm{~m}$ \\
\hline 59 & $35^{\circ} 19^{\prime} 47.72^{\prime \prime} \mathrm{B} / 25^{\circ} 6^{\prime} 58.79^{\prime \prime} \mathrm{A}$ & Taxis & Fast charger, DC 50 kW & 2 & Ground-mounted & $\begin{array}{l}\text { 59.1: } 2.5 \mathrm{~m} \times 5 \mathrm{~m} \\
\text { 59.2: } 2.5 \mathrm{~m} \times 5 \mathrm{~m}\end{array}$ \\
\hline 60 & $35^{\circ} 20^{\prime} 1.30^{\prime \prime} \mathrm{B} / 25^{\circ} 8^{\prime} 18.54^{\prime \prime} \mathrm{A}$ & Taxis & Fast charger, DC $50 \mathrm{~kW}$ & 1 & Ground-mounted & 60.1: $2.5 \mathrm{~m} \times 5 \mathrm{~m}$ \\
\hline 61 & $35^{\circ} 18^{\prime} 19.28^{\prime \prime} \mathrm{B} / 25^{\circ} 9^{\prime} 14.08^{\prime \prime} \mathrm{A}$ & Taxis & Fast charger, DC $50 \mathrm{~kW}$ & 2 & Ground-mounted & $\begin{array}{l}\text { 61.1: } 2.5 \mathrm{~m} \times 5 \mathrm{~m} \\
\text { 61.2: } 2.5 \mathrm{~m} \times 5 \mathrm{~m}\end{array}$ \\
\hline 62 & $35^{\circ} 20^{\prime} 11.32^{\prime \prime} \mathrm{B} / 25^{\circ} 8^{\prime} 47.38^{\prime \prime} \mathrm{A}$ & Taxis & Fast charger, DC 50 kW & 1 & Ground-mounted & 62.1: $2.5 \mathrm{~m} \times 5 \mathrm{~m}$ \\
\hline 64 & $35^{\circ} 19^{\prime} 9.98^{\prime \prime} \mathrm{B} / 25^{\circ} 6^{\prime} 6.95^{\prime \prime} \mathrm{A}$ & Passenger (single-family) cars & $\mathrm{AC} 22 \mathrm{~kW}$ & 2 & Ground-mounted & $\begin{array}{l}\text { 64.1: } 2.5 \mathrm{~m} \times 5 \mathrm{~m} \\
64.2: 2.5 \mathrm{~m} \times 5 \mathrm{~m}\end{array}$ \\
\hline 65 & $35^{\circ} 18^{\prime} 34.04^{\prime \prime} \mathrm{B} / 25^{\circ} 6^{\prime} 9.35^{\prime \prime} \mathrm{A}$ & Buses & Fast charger, DC 50 kW & 1 & Ground-mounted & 65.1: $3 \mathrm{~m} \times 14 \mathrm{~m}$ \\
\hline 66 & $35^{\circ} 18^{\prime} 18.67^{\prime \prime} \mathrm{B} / 25^{\circ} 5^{\prime} 4.79^{\prime \prime} \mathrm{A}$ & Passenger (single-family) cars & $\mathrm{AC} 22 \mathrm{~kW}$ & 2 & Ground-mounted & $\begin{array}{l}\text { 66.1: } 2.5 \mathrm{~m} \times 5 \mathrm{~m} \\
66.2: 2.5 \mathrm{~m} \times 5 \mathrm{~m}\end{array}$ \\
\hline 67 & $35^{\circ} 18^{\prime} 18.58^{\prime \prime} \mathrm{B} / 25^{\circ} 5^{\prime} 4.91^{\prime \prime} \mathrm{A}$ & Passenger (single-family) cars & AC $22 \mathrm{~kW}$ & 2 & Ground-mounted & $\begin{array}{l}\text { 67.1: } 2.5 \mathrm{~m} \times 5 \mathrm{~m} \\
67.2: 2.5 \mathrm{~m} \times 5 \mathrm{~m}\end{array}$ \\
\hline 68 & $35^{\circ} 18^{\prime} 33.00^{\prime \prime} \mathrm{B} / 25^{\circ} 4^{\prime} 54.35^{\prime \prime} \mathrm{A}$ & Passenger (single-family) cars & $\mathrm{AC} 22 \mathrm{~kW}$ & 2 & Ground-mounted & $\begin{array}{l}\text { 68.1: } 2.5 \mathrm{~m} \times 5 \mathrm{~m} \\
\text { 68.2: } 2.5 \mathrm{~m} \times 5 \mathrm{~m}\end{array}$ \\
\hline 69 & $35^{\circ} 18^{\prime} 30.92^{\prime \prime} \mathrm{B} / 25^{\circ} 5^{\prime} 4.57^{\prime \prime} \mathrm{A}$ & Buses + passenger cars & Fast charger, DC $50 \mathrm{~kW}$ & 2 & Ground-mounted & $\begin{array}{l}\text { 69.1: } 2.5 \mathrm{~m} \times 5 \mathrm{~m} \\
69.2: 2.5 \mathrm{~m} \times 5 \mathrm{~m}\end{array}$ \\
\hline 70 & $35^{\circ} 18^{\prime} 20.67^{\prime \prime} \mathrm{B} / 25^{\circ} 4^{\prime} 26.19^{\prime \prime} \mathrm{A}$ & Passenger (single-family) cars & $\mathrm{AC} 22 \mathrm{~kW}$ & 2 & Ground-mounted & $\begin{array}{l}\text { 70.1: } 2.5 \mathrm{~m} \times 5 \mathrm{~m} \\
70.2: 2.5 \mathrm{~m} \times 5 \mathrm{~m}\end{array}$ \\
\hline
\end{tabular}


Table A1. Cont.

\begin{tabular}{|c|c|c|c|c|c|c|}
\hline No. * & $\begin{array}{c}\text { Geographical Coordinates, } \\
\text { Latitude/Longitude }\end{array}$ & Primary Vehicles Charged & Charger Type & No. of Parking Spaces & Installation & $\begin{array}{c}\text { No. of Spaces and } \\
\text { Indicative Dimensions }\end{array}$ \\
\hline 71 & $35^{\circ} 18^{\prime} 18.02^{\prime \prime} \mathrm{B} / 25^{\circ} 9^{\prime} 20.61^{\prime \prime} \mathrm{A}$ & Passenger (single-family) cars & $\mathrm{AC} 22 \mathrm{~kW}$ & 2 & Ground-mounted & $\begin{array}{l}\text { 71.1: } 2.5 \mathrm{~m} \times 5 \mathrm{~m} \\
\text { 71.2: } 2.5 \mathrm{~m} \times 5 \mathrm{~m}\end{array}$ \\
\hline 72 & $35^{\circ} 18^{\prime} 17.94^{\prime \prime} \mathrm{B} / 25^{\circ} 9^{\prime} 20.35^{\prime \prime} \mathrm{A}$ & Passenger (single-family) cars & $\mathrm{AC} 22 \mathrm{~kW}$ & 2 & Ground-mounted & $\begin{array}{l}\text { 72.1: } 2.5 \mathrm{~m} \times 5 \mathrm{~m} \\
\text { 72.2: } 2.5 \mathrm{~m} \times 5 \mathrm{~m}\end{array}$ \\
\hline 73 & $35^{\circ} 18^{\prime} 32.16^{\prime \prime} \mathrm{B} / 25^{\circ} 9^{\prime} 6.25^{\prime \prime} \mathrm{A}$ & Passenger (single-family) cars & $\mathrm{AC} 22 \mathrm{~kW}$ & 2 & Ground-mounted & $\begin{array}{l}\text { 73.1: } 2.5 \mathrm{~m} \times 5 \mathrm{~m} \\
\text { 73.2: } 2.5 \mathrm{~m} \times 5 \mathrm{~m}\end{array}$ \\
\hline 75 & $35^{\circ} 19^{\prime} 29.80^{\prime \prime} \mathrm{B} / 25^{\circ} 7^{\prime} 47.51^{\prime \prime} \mathrm{A}$ & Taxis & Fast charger, DC $50 \mathrm{~kW}$ & 1 & Ground-mounted & 75.1: $2.5 \mathrm{~m} \times 5 \mathrm{~m}$ \\
\hline 76 & $35^{\circ} 19^{\prime} 47.76^{\prime \prime} \mathrm{B} / 25^{\circ} 8^{\prime} 28.43^{\prime \prime} \mathrm{A}$ & Passenger (single-family) cars & $\mathrm{AC} 22 \mathrm{~kW}$ & 2 & Ground-mounted & $\begin{array}{l}\text { 76.1: } 2.5 \mathrm{~m} \times 5 \mathrm{~m} \\
\text { 76.2: } 2.5 \mathrm{~m} \times 5 \mathrm{~m}\end{array}$ \\
\hline 77 & $35^{\circ} 19^{\prime} 47.59^{\prime \prime} \mathrm{B} / 25^{\circ} 8^{\prime} 28.59^{\prime \prime} \mathrm{A}$ & Passenger (single-family) cars & $\mathrm{AC} 22 \mathrm{~kW}$ & 2 & Ground-mounted & $\begin{array}{l}\text { 77.1: } 2.5 \mathrm{~m} \times 5 \mathrm{~m} \\
\text { 77.2: } 2.5 \mathrm{~m} \times 5 \mathrm{~m}\end{array}$ \\
\hline 78 & $35^{\circ} 20^{\prime} 12.49^{\prime \prime} \mathrm{B} / 25^{\circ} 8^{\prime} 16.11^{\prime \prime} \mathrm{A}$ & Passenger (single-family) cars & $\mathrm{AC} 22 \mathrm{~kW}$ & 2 & Ground-mounted & $\begin{array}{l}\text { 78.1: } 2.5 \mathrm{~m} \times 5 \mathrm{~m} \\
78.2: 2.5 \mathrm{~m} \times 5 \mathrm{~m}\end{array}$ \\
\hline 79 & $35^{\circ} 20^{\prime} 12.39^{\prime \prime} \mathrm{B} / 25^{\circ} 8^{\prime} 16.53^{\prime \prime} \mathrm{A}$ & Passenger (single-family) cars & $\mathrm{AC} 22 \mathrm{~kW}$ & 2 & Ground-mounted & $\begin{array}{l}\text { 79.1: } 2.5 \mathrm{~m} \times 5 \mathrm{~m} \\
\text { 79.2: } 2.5 \mathrm{~m} \times 5 \mathrm{~m}\end{array}$ \\
\hline 80 & $35^{\circ} 20^{\prime} 16.20^{\prime \prime} \mathrm{B} / 25^{\circ} 8^{\prime} 5.23^{\prime \prime} \mathrm{A}$ & Passenger (single-family) cars & Fast charger, DC $50 \mathrm{~kW}$ & 1 & Ground-mounted & 80.1: $2.5 \mathrm{~m} \times 5 \mathrm{~m}$ \\
\hline 81 & $35^{\circ} 20^{\prime} 20.62^{\prime \prime} \mathrm{B} / 25^{\circ} 8^{\prime} 17.05^{\prime \prime} \mathrm{A}$ & Passenger (single-family) cars & $\mathrm{AC} 22 \mathrm{~kW}$ & 2 & Ground-mounted & $\begin{array}{l}\text { 81.1: } 2.5 \mathrm{~m} \times 5 \mathrm{~m} \\
\text { 81.2: } 2.5 \mathrm{~m} \times 5 \mathrm{~m}\end{array}$ \\
\hline 82 & $35^{\circ} 19^{\prime} 55.64^{\prime \prime} \mathrm{B} / 25^{\circ} 7^{\prime} 57.01^{\prime \prime} \mathrm{A}$ & Passenger (single-family) cars & $\mathrm{AC} 22 \mathrm{~kW}$ & 2 & Ground-mounted & $\begin{array}{l}\text { 82.1: } 2.5 \mathrm{~m} \times 5 \mathrm{~m} \\
\text { 82.2: } 2.5 \mathrm{~m} \times 5 \mathrm{~m}\end{array}$ \\
\hline 83 & $35^{\circ} 19^{\prime} 55.92^{\prime \prime} \mathrm{B} / 25^{\circ} 7^{\prime} 57.32^{\prime \prime} \mathrm{A}$ & Passenger (single-family) cars & $\mathrm{AC} 22 \mathrm{~kW}$ & 2 & Ground-mounted & $\begin{array}{l}\text { 83.1: } 2.5 \mathrm{~m} \times 5 \mathrm{~m} \\
\text { 83.2: } 2.5 \mathrm{~m} \times 5 \mathrm{~m}\end{array}$ \\
\hline 84 & $35^{\circ} 20^{\prime} 5.71^{\prime \prime} \mathrm{B} / 25^{\circ} 7^{\prime} 39.83^{\prime \prime} \mathrm{A}$ & Passenger (single-family) cars & $\mathrm{AC} 22 \mathrm{~kW}$ & 2 & Ground-mounted & $\begin{array}{l}\text { 84.1: } 2.5 \mathrm{~m} \times 5 \mathrm{~m} \\
\text { 84.2: } 2.5 \mathrm{~m} \times 5 \mathrm{~m}\end{array}$ \\
\hline 85 & $35^{\circ} 19^{\prime} 43.80^{\prime \prime} \mathrm{B} / 25^{\circ} 8^{\prime} 14.97^{\prime \prime} \mathrm{A}$ & Taxis & Fast charger, DC $50 \mathrm{~kW}$ & 1 & Ground-mounted & 85.1: $2.5 \mathrm{~m} \times 5 \mathrm{~m}$ \\
\hline 86 & $35^{\circ} 20^{\prime} 15.96^{\prime \prime} \mathrm{B} / 25^{\circ} 8^{\prime} 31.89^{\prime \prime} \mathrm{A}$ & Passenger (single-family) cars & $\mathrm{AC} 22 \mathrm{~kW}$ & 2 & Ground-mounted & $\begin{array}{l}\text { 86.1: } 2.5 \mathrm{~m} \times 5 \mathrm{~m} \\
\text { 86.2: } 2.5 \mathrm{~m} \times 5 \mathrm{~m}\end{array}$ \\
\hline
\end{tabular}


Table A1. Cont.

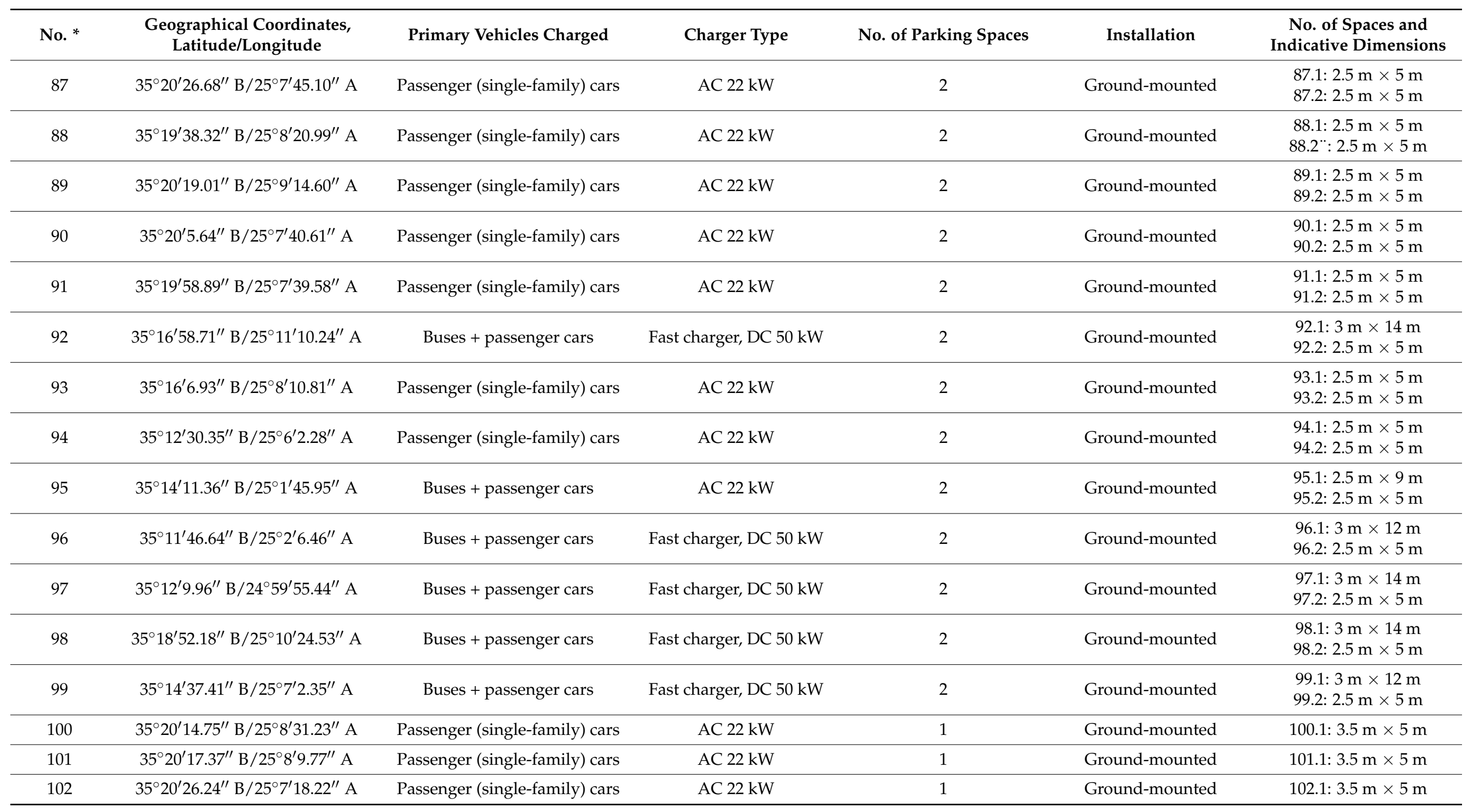


Table A1. Cont.

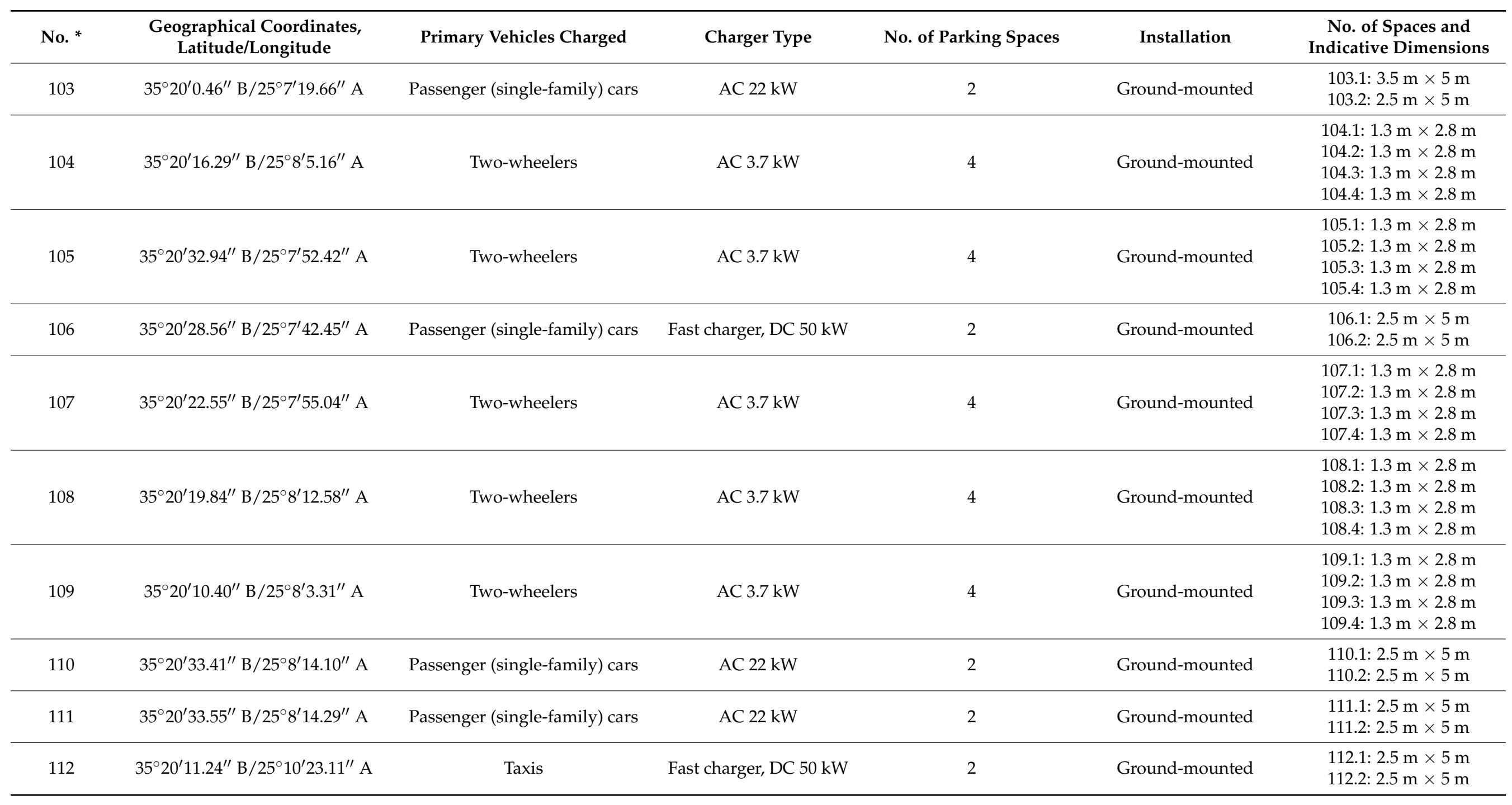


Table A1. Cont.

\begin{tabular}{|c|c|c|c|c|c|c|}
\hline No. * & $\begin{array}{l}\text { Geographical Coordinates, } \\
\text { Latitude/Longitude }\end{array}$ & Primary Vehicles Charged & Charger Type & No. of Parking Spaces & Installation & $\begin{array}{c}\text { No. of Spaces and } \\
\text { Indicative Dimensions }\end{array}$ \\
\hline 113 & $35^{\circ} 19^{\prime} 18.09^{\prime \prime} \mathrm{B} / 25^{\circ} 9^{\prime} 29.15^{\prime \prime} \mathrm{A}$ & Buses + passenger cars & Fast charger, DC $50 \mathrm{~kW}$ & 2 & Ground-mounted & $\begin{array}{l}\text { 113.1: } 3 \mathrm{~m} \times 14 \mathrm{~m} \\
\text { 113.2: } 2.5 \mathrm{~m} \times 5 \mathrm{~m}\end{array}$ \\
\hline 114 & $35^{\circ} 18^{\prime} 44.28^{\prime \prime} \mathrm{B} / 25^{\circ} 8^{\prime} 41.85^{\prime \prime} \mathrm{A}$ & Passenger (single-family) cars & $\mathrm{AC} 22 \mathrm{~kW}$ & 2 & Ground-mounted & $\begin{array}{l}\text { 114.1: } 2.5 \mathrm{~m} \times 5 \mathrm{~m} \\
\text { 114.2: } 2.5 \mathrm{~m} \times 5 \mathrm{~m}\end{array}$ \\
\hline 115 & $35^{\circ} 18^{\prime} 48.80^{\prime \prime} \mathrm{B} / 25^{\circ} 8^{\prime} 38.27^{\prime \prime} \mathrm{A}$ & Two-wheelers & AC $3.7 \mathrm{~kW}$ & 4 & Ground-mounted & $\begin{array}{l}\text { 115.1: } 1.3 \mathrm{~m} \times 2.8 \mathrm{~m} \\
\text { 115.2: } 1.3 \mathrm{~m} \times 2.8 \mathrm{~m} \\
\text { 115.3: } 1.3 \mathrm{~m} \times 2.8 \mathrm{~m} \\
\text { 115.4: } 1.3 \mathrm{~m} \times 2.8 \mathrm{~m}\end{array}$ \\
\hline E116 & $35^{\circ} 19^{\prime} 28.24^{\prime \prime} \mathrm{B} / 25^{\circ} 10^{\prime} 55.35^{\prime \prime} \mathrm{A}$ & $\begin{array}{c}\text { Minibuses } \\
\text { (ECOROUTS project) }\end{array}$ & DC $2 \times 6 \mathrm{~kW}$ & 1 & Ground-mounted & 104.1: $2.5 \mathrm{~m} \times 6.5 \mathrm{~m}$ \\
\hline E117 & $35^{\circ} 19^{\prime} 28.31^{\prime \prime} \mathrm{B} / 25^{\circ} 10^{\prime} 55.55^{\prime \prime} \mathrm{A}$ & $\begin{array}{c}\text { Minibuses } \\
\text { (ECOROUTS project) }\end{array}$ & $\mathrm{DC} 2 \times 6 \mathrm{~kW}$ & 1 & Ground-mounted & 104.2: $2.5 \mathrm{~m} \times 6.5 \mathrm{~m}$ \\
\hline E118 & $35^{\circ} 20^{\prime} 3.91^{\prime \prime} \mathrm{B} / 25^{\circ} 9^{\prime} 31.16^{\prime \prime} \mathrm{A}$ & Passenger (single-family) cars & $\mathrm{AC} 22 \mathrm{~kW}$ & 1 & Ground-mounted & $\mathrm{N} / \mathrm{A}$ \\
\hline E119 & $35^{\circ} 20^{\prime} 12.60^{\prime \prime} \mathrm{B} / 25^{\circ} 9^{\prime} 20.80^{\prime \prime} \mathrm{A}$ & Passenger (single-family) cars & AC $7 \mathrm{~kW}$ & 1 & Ground-mounted & $\mathrm{N} / \mathrm{A}$ \\
\hline E121 & $35^{\circ} 20^{\prime} 17.00^{\prime \prime} \mathrm{B} / 25^{\circ} 7^{\prime} 19.60^{\prime \prime} \mathrm{A}$ & Passenger (single-family) cars & $\mathrm{AC} 22 \mathrm{~kW}$ & 1 & Ground-mounted & $\mathrm{N} / \mathrm{A}$ \\
\hline E122 & $35^{\circ} 18^{\prime} 7.88^{\prime \prime} \mathrm{B} / 25^{\circ} 5^{\prime} 30.94^{\prime \prime} \mathrm{A}$ & Passenger (single-family) cars & $\mathrm{AC} 22 \mathrm{~kW}$ & 1 & $\mathrm{~N} / \mathrm{A}$ & $\mathrm{N} / \mathrm{A}$ \\
\hline
\end{tabular}

* Numbers with the initial " $\mathrm{E}$ " mean the existing chargers. 


\section{References}

1. Sanguesa, J.A.; Torres-Sanz, V.; Garrido, P.; Martinez, F.J.; Marquez-Barja, J.M. A review on electric vehicles: Technologies and challenges. Smart Cities 2021, 4, 372-404. [CrossRef]

2. Asuah, A.; Zumelzu, A. Measuring urban diversities in cities in transformation: Case of Temuco, Chile. IOP Conf. Ser. Earth Environ. Sci. 2020, 503, 012085. [CrossRef]

3. Yigitcanlar, T.; Cugurullo, F. The sustainability of artificial intelligence: An urbanistic viewpoint from the lens of smart and sustainable cities. Sustainability 2020, 12, 8548. [CrossRef]

4. Jabareen, Y.R. Sustainable urban forms: Their typologies, models, and concepts. J. Plan. Educ. Res. 2006, 26, 38-52. [CrossRef]

5. International Energy Agency. Global EV Outlook 2016; OCED: Paris, France, 2016.

6. Bayissa, B.B.; Baiqing, S.; Lixin, Q. Sustainable transport infrastructure and economic returns: A bibliometric and visualization analysis. Sustainability 2020, 12, 2033.

7. Pollák, F.; Vodák, J.; Soviar, J.; Markovič, P.; Lentini, G.; Mazzeschi, V.; Luè, A. Promotion of electric mobility in the European Union-Overview of project PROMETEUS from the perspective of cohesion through synergistic cooperation on the example of the catching-up region. Sustainability 2021, 13, 1545. [CrossRef]

8. Dijk, M.; Orsato, R.J.; Kemp, R. The emergence of an electric mobility trajectory. Energy Policy 2013, 52, 135-145. [CrossRef]

9. Efthymiou, D.; Chrysostomou, K.; Morfoulaki, M.; Aifantopoulou, G. Electric vehicles charging infrastructure location: A genetic algorithm approach. Eur. Transp. Res. Rev. 2017, 9, 27. [CrossRef]

10. Farid, A.M.; Viswanath, A.; Al-Junaibi, R.; Allan, D.; Van der Wardt, T.J.T. Electric vehicle integration into road transportation, intelligent transportation, and electric power systems: An Abu Dhabi case study. Smart Cities 2021, 4, 1039-1057. [CrossRef]

11. Statharas, S.; Moysoglou, Y.; Siskos, P.; Zazias, G.; Capros, P. Factors influencing electric vehicle penetration in the EU by 2030: A model-based policy assessment. Energies 2019, 12, 2739. [CrossRef]

12. Thiel, C.; Tsakalidis, A.; Jäger-Waldau, A. Will electric vehicles be killed (again) or are they the next mobility killer app? Energies 2020, 13, 1828. [CrossRef]

13. Dimitropoulou, M.; Tsikalakis, A.; Gigantidou, A.; Thalassinakis, E.; Pylarinos, D. Estimation of Hosting Electric Vehicles Capacity in the Transformers on the Island of Crete; Engineering and Industry Series; Volume Power Systems, Energy Markets and Renewable Energy Sources in South-Eastern Europe; Trivent Publishing: Budapest, Hungary, 2016; pp. 235-246.

14. Morais, H.; Sousa, T.; Vale, Z.; Faria, P. Evaluation of the electric vehicle impact in the power demand curve in a smart grid environment. Energy Convers. Manag. 2014, 82, 268-282. [CrossRef]

15. Knezovic, K.; Marinelli, M.; Zecchino, A.; Andersen, P.B.; Traeholt, C. Supporting involvement of electric vehicles in distribution grids: Lowering the barriers for a proactive integration. Energy 2017, 134, 458-468. [CrossRef]

16. Wu, F.; Sioshansi, R. A two-stage stochastic optimization model for scheduling electric vehicle charging loads to relieve distribution-system constraints. Transp. Res. B 2017, 102, 55-82. [CrossRef]

17. Hu, J.; You, S.; Lind, M.; Østergaard, J. Coordinated charging of electric vehicles for congestion prevention in the distribution grid. IEEE Trans. Smart Grid 2014, 5, 703-711. [CrossRef]

18. Zagorskas, J.; Burinskienè, M. Challenges caused by increased use of e-powered personal mobility vehicles in european cities. Sustainability 2020, 12, 273. [CrossRef]

19. Ribeiro, P.; Dias, G.; Pereira, P. Transport systems and mobility for smart cities. Appl. Syst. Innov. 2021, 4, 61. [CrossRef]

20. Wang, C.; Steinfeld, E.; Maisel, J.; Kang, B. Is your smart city inclusive? Evaluating proposals from the U.S. department of transportation's smart city challenge. Sustain. Cities Soc. 2021, 74, 103148. [CrossRef]

21. Karfopoulos, E.; Hatziargyriou, N. A multi-agent system for controlled charging of a large population of electric vehicles. IEEE Trans. Power Syst. 2013, 28, 1196-1204. [CrossRef]

22. Karfopoulos, E.; Hatziargyriou, N. Distributed coordination of electric vehicles for conforming to an energy schedule. Electr. Power Syst. Res. 2017, 151, 86-95. [CrossRef]

23. Spanoudakis, P.; Tsourveloudis, N.C.; Doitsidis, L.; Karapidakis, E.S. Experimental research of transmissions on electric vehicles' energy consumption. Energies 2019, 12, 388. [CrossRef] 